Original article

Section: Food Quality and Functionality

\title{
Phenolic Composition, and Antioxidant and Antineurodegenerative Potential of Methanolic Extracts of Fruit Peel and Flesh of Pear Varieties from Serbia
}

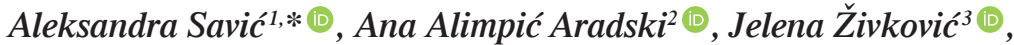 \\ Katarina Šavikin ${ }^{3}$ (1), Snežana Jarićc ${ }^{4}$ (1), Petar D. Marin ${ }^{2}$ (D), Sonja Duletić-Laušević ${ }^{\text {(1) }}$ \\ ${ }^{1}$ Natural History Museum in Belgrade, Njegoševa 51, 11000 Belgrade, Serbia \\ 2Institute of Botany and Botanical Garden "Jevremovac", Faculty of Biology, \\ University of Belgrade, Takovska 43, 11000 Belgrade, Serbia \\ ${ }^{3}$ Institute for Medicinal Plant Research 'Dr Josif Pančić', Tadeuša Košćuška 1, 11000 Belgrade, Serbia \\ ${ }^{4}$ Department of Ecology, Institute for Biological Research 'Siniša Stanković' - National Institute of the Republic of Serbia, \\ University of Belgrade, Bulevar Despota Stefana 142, 11060 Belgrade, Serbia
}

Key words: pear fruit, traditional varieties, methanolic extracts, phenolic composition, antioxidant activity, antineurodegenerative activity

Pear (Pyrus communis L.) is consumed as fresh fruit, in numerous food products, and also used as a traditional remedy in various countries, including Serbia. In search of bioactive compounds, six traditional pear varieties ('Vidovača', 'Lubeničarka', 'Karamanka', 'Jeribasma', 'Lončara', 'Takiša') and wild pear from Serbia were investigated and compared with a commercial variety ('Williams Bartlett'). The aim of this study was to determine the total phenolic and flavonoid contents, phenolic composition, antioxidant capacity, and antineurodegenerative activities of methanolic extracts of peel, flesh, and mixed peel and flesh of pear fruits. Phenolic composition of extracts was determined with HPLC-DAD, while the antioxidant activity of extracts was evaluated by 2,2-diphenyl-1-picrylhydrazyl (DPPH), 2,2'-azino-bis(3-ethylbenzothiazoline-6-sulphonic acid) (ABTS), and ferric-reducing antioxidant power (FRAP) assays. Bearing in mind that oxidative stress is closely linked to neurodegeneration, the antineurodegenerative potential of the extracts was assessed by the inhibition of acetycholineserase (AChE) and tyrosinase (TYR) activities. The extracts of traditional varieties, particularly peel extracts, had a high content of phenolics, as well as significant antioxidant and moderate antineurodegenerative potential, compared to the commercial variety. The highest contents of total flavonoids and individual compounds, such as arbutin and chlorogenic acid, as well as the strongest antioxidant and TYR inhibitory activities were reported for the 'Takiša' peel extract. The performed analyses have revealed that fruits of traditional Serbian pear varieties are rich in bioactive components and could be used as functional food and for possible nutraceutical applications, to prevent diseases induced by oxidative stress.

\section{ABBREVIATIONS}

TPC, total phenolic content; TFC, total flavonoid content; DPPH, 2,2-diphenyl-1-picrylhydrazyl; ABTS, 2,2'-azino-bis(3-ethylbenzothiazoline-6-sulfonic acid); FRAP, ferric-reducing antioxidant power; BHA, 2(3)-tert-butyl-4-hydroxyanisole; BHT, 3,5-di-tert-butyl-4-hydroxytoluene; TPTZ, 2,4,6-tripyridyl-s-triazine; L-DOPA, 3,4-dihydroxy-L-phenylalanine; AAE, ascorbic acid equivalents; DTNB, 5,5'-dithiobis(2-nitrobenzoic acid); AChE, acetylcholinesterase; TYR, tyrosinase; HPLC-DAD, high-performance liquid chromatography with diode array detection.

\section{INTRODUCTION}

Pear (Pyrus communis L.), belonging to the Rosaceae family, is one of the most widespread fruits in the world. It is the fifth most produced fruit worldwide, but, despite over 3000 pear cultivars, there are only a few dozen globally produced pear varieties [Brahem et al., 2017]. Because of their desirable taste and good digestibility, pears are widely consumed as fresh or dry fruits, juices, and numerous products.

The pear has been used as a traditional remedy in China for more than 2000 years [Li et al., 2012, 2014; Reiland \& Slavin, 2015], and also in Ancient Greece [Parle \& Arzoo, 2016]. Ethnobotanical surveys of the traditional use of $P$. communis $\mathrm{L}$. fruit have shown similar usability of pear for consumption and medicinal purposes (against hypertension, diabetes, high cholesterol, constipation, as uroseptic,

\footnotetext{
* Corresponding Author:

E-mail aleksandra.savic@nhmbeo.rs (A. Savić)
} 
antirheumatic, for body mass reduction) also in the Balkan region [Dajić-Stevanović et al., 2014; Savić et al., 2019]. Several previous studies investigated fruits, their nutritional components, and bioactivities of flesh and peel of different pear varieties grown worldwide [Kolniak-Ostek, 2016; Kolniak-Ostek et al., 2020; Li at al., 2014, 2016b; Liaudanskas et al., 2017; Öztürk et al., 2015; Reiland \& Slavin 2015; Salta et al., 2010; Sharma et al., 2015]. Additionally, several investigations proved that, besides fruit, each part of the pear tree (leaves, bark, root) possesses phenolics with notable antioxidant activities [Carbonaro et al., 2002; Imeh \& Khokhar, 2002], providing numerous health benefits [Kolniak-Ostek, 2016; Öztürk et al., 2015; Parle \& Arzoo 2016].

The health-promoting, nutritional, and sensorial quality of the pear fruit is influenced by the pear species and variety from which it originates. Chemical composition analyses of pear fruits have demonstrated that they represent essential sources of sugars, vitamins, amino acids, minerals, phenolics, organic acids, and other chemical constituents important for human nutrition and health boosting [Li et al., 2012, 2014; Salta et al., 2010]. Phenolics in the pear fruit contribute to its sensory quality and are strongly linked to many health benefits and antioxidant activity [Brahem et al., 2017]. Phenolic compounds are more concentrated in the peel of the fruit, compared to flesh [Brahem et al., 2017; Li et al., 2014; Kolniak-Ostek, 2016].

The studies of chemical composition of pear fruit revealed the presence of phenolics, such as arbutin, (-)-epicatechin, quercitrin, isoquercitrin, kaempferol, astragalin, tannins, as well as triterpenoids including friedelin, squalene, sterols, and saponins [Kaur \& Arya, 2012; Kolniak-Ostek, 2016; Liaudanskas et al., 2017; Sharma et al., 2015]. Phenolic acids (chlorogenic, syringic, ferulic, and coumaric acids) [Lin \& Harnly, 2008; Salta et al., 2010; Sharma et al., 2015], organic acids (malic, citric, and shikimic acids), as well as vitamins $\mathrm{C}$ and $\mathrm{E}$ were also detected in pear fruits [Kolniak-Ostek, 2016; Öztürk et al., 2015].

Methanol is commonly used to extract phenolics from fruit parts [Chel-Guerrero et al., 2018]. The chemical analyses performed by Li et al. [2012] and Öztürk et al. [2015] revealed that methanolic extracts of pear fruit contained phenolic compounds, such as chlorogenic acid, arbutin, (+)-catechin, and (-)-epicatechin, followed by quercetin and rutin, predominantly in the peel. In addition to a high content of the phenolics, the peel is an excellent source of triterpenoids [Kolniak-Ostek, 2016; Li et al., 2014].

The phenolic compounds are well known for their antioxidant activity. The antiviral activity of specific flavonoid groups, such as flavanones, flavonols, and catechins, has also been reported against various viral strains, as well as SARS-CoV and MERS-CoV, which suggests that functional food has a huge potential to strengthen the immune system and provide treatment for the ongoing epidemic of COVID-19 [Adem et al., 2020]. Besides, phenolic compounds of various fruits can play a beneficial therapeutic role in the treatment of oxidative stress-induced neurodegenerative disorders, such as Alzheimer's disease and Parkinson's disease [Wilson et al., 2017].

The aim of the present study was to evaluate and compare the total phenolic and flavonoid contents, the phenolic composition, as well as the antioxidant and antineurodegenerative activities of methanolic extracts of peel, flesh, and mixed peel and flesh of six traditional and rare pear varieties from Serbia ('Vidovača', 'Lubeničarka', 'Karamanka', 'Jeribasma', 'Lončara', and 'Takiša'), and wild pear, and comparing them to one commercial variety ('Williams Bartlett'). Additionally, the correlations were established between the content of phenolics and flavonoids and bioactivities tested. The mentioned pear varieties have never been studied before for chemical composition and bioactivities, hence they were subjected to detailed analyses.

\section{MATERIALS AND METHODS}

\section{Chemicals}

Ascorbic acid, gallic acid, 2,2-diphenyl-1-picrylhydrazyl radical $\left(\mathrm{DPPH}^{*}\right), 2,2$ '-azino-bis(3-ethylbenzothiazoline-6-sulfonic acid) diammonium salt (ABTS), 2(3)-tert-butyl-4-hydroxyanisole (BHA), 3,5-di-tert-butyl-4-hydroxytoluene (BHT), 2,4,6-tripyridyl-s-triazine (TPTZ), potassium acetate $\left(\mathrm{C}_{2} \mathrm{H}_{3} \mathrm{KO}_{2}\right)$, potassium-persulfate $\left(\mathrm{K}_{2} \mathrm{~S}_{2} \mathrm{O}_{8}\right)$, dimethyl sulfoxide, aluminum nitrate nonahydrate $\left(\mathrm{Al}\left(\mathrm{NO}_{3}\right)_{3} \times 9 \mathrm{H}_{2} \mathrm{O}\right)$, Folin-Ciocalteu reagent, sodium acetate $\left(\mathrm{CH}_{3} \mathrm{COONa}\right)$, sodium carbonate anhydrous $\left(\mathrm{Na}_{2} \mathrm{CO}_{3}\right)$, iron(III) chloride $\left(\mathrm{FeCl}_{3}\right)$, iron(II) sulfate heptahydrate $\left(\mathrm{FeSO}_{4} \times 7 \mathrm{H}_{2} \mathrm{O}\right)$, sodium phosphate monobasic $\left(\mathrm{NaH}_{2} \mathrm{PO}_{4}\right)$, sodium phosphate dibasic $\left(\mathrm{Na}_{2} \mathrm{HPO}_{4}\right)$, 5,5'-dithiobis(2-nitrobenzoic acid) (DTNB), acetylcholine iodide, acetylcholinesterase from Electrophorus electricus (AChE), galanthamine hydrobromide from Lycoris sp., tyrosinase from mushroom, kojic acid, 3,4-dihydroxy-L-phenylalanine (L-DOPA), rutin hydrate (94\%, HPLC), chlorogenic acid (95\%, titration), hyperoside (97\%, HPLC), arbutin (96\%, HPLC), isoquercitrin (90\%, HPLC), procyanidin $\mathrm{B}_{1}\left(\geq 90 \%\right.$, HPLC) and procyanidin $\mathrm{B}_{2}(>90 \%$, HPLC), formic acid (98-100\%), and acetonitrile (99.8\%) were purchased from Sigma Aldrich (St. Louis, MO, USA). Other used chemicals, such as ethanol, methanol, glacial acetic acid, and hydrochloric acid, were purchased from Zorka Pharma, Šabac (Serbia). Quercitrin (98.5\%, HPLC) was purchased from Extrasynthese (Genay, France). Water was deionized using a MilliQ system (Millipore, Bedford, MA, USA).

\section{Plant material}

Fruits of eight different pear varieties were analyzed in this study (Figure 1). Among them, six are traditional varieties from organic production: 'Vidovača', 'Lubeničarka', 'Karamanka', 'Jeribasma', 'Takiša', 'Lončara' (from the hoods in central Serbia - Šumadija region), wild pear was collected from southwest Serbia, while fruits of commercial variety 'Williams Bartlett' were purchased at a local market. Fruits were sampled in 2016, at their optimal ripening stage recommended for consumption (from July till October). The collected material was stored at $-20^{\circ} \mathrm{C}$ until the extracts preparation.

The fruit sizes varied between varieties: from approximately 20-25 g (wild pear and 'Takiša'); 30-50 g ('Vidovača' and Lubeničarka); 120-220 g ('Williams Bartlett', 'Karamanka', 'Jeribasma') to 220-280 g ('Lončara'). In the case of smaller fruits (wild pear, 'Takiša', 'Vidovača' and 'Lubeničarka'), 4-10 fruits were used for the extraction; and in the case of the larger ones ('Williams Bartlett', 'Karamanka', 'Jeribasma', 'Lončara'), 1-2 fruits were used. 


\section{Preparation of extracts}

Before extracts preparation, the frozen fruits were peeled (skin thickness approx. $0.5 \mathrm{~mm}$ ) for the peel sample, and mashed in the jar. The mixed peel and flesh, and pure flesh samples were cut into cubes $\left(1 \mathrm{~cm}^{3}\right)$ and separately homogenized using a laboratory blender (No. 8010ES, Waring ${ }^{\circledR}$ Laboratory Science, Torrington, CT, USA). The pear extracts were prepared using methanol as followed: $10 \mathrm{~g}$ of peel were extracted with $10 \mathrm{~mL}$ of methanol; $30 \mathrm{~g}$ of flesh were extracted with $30 \mathrm{~mL}$ of methanol, and $30 \mathrm{~g}$ of peel and flesh were extracted with $30 \mathrm{~mL}$ of methanol. The extractions of the material were performed three times, every $24 \mathrm{~h}$ for $72 \mathrm{~h}$ at room temperature. The obtained liquid extracts were mixed and filtered (Whatman No.1) and subsequently concentrated under reduced pressure (rotavapor R-114, BÜCHI Labortechnik AG, Flawil, Switzerland). Yields of crude extracts were calculated and dry extracts were subsequently stored at $+4^{\circ} \mathrm{C}$. Stock solutions were prepared in methanol in a concentration of $1 \mathrm{mg} / \mathrm{mL}$ freshly before experiments.

\section{Determination of total phenolic content}

The total phenolic content of pear extracts was measured spectrophotometrically [Singleton \& Rossi, 1965] with slight modification. The reaction mixture containing $0.2 \mathrm{~mL}$ of the extract in concentration of $1 \mathrm{mg} / \mathrm{mL}, 1.0 \mathrm{~mL}$ of $10 \%$ Folin-Ciocalteu reagent, and $0.8 \mathrm{~mL}$ of $7.5 \% \mathrm{Na}_{2} \mathrm{CO}_{3}$ were incubated for $2 \mathrm{~h}$, at room temperature in the dark. Distilled water was used as a blank, while control was prepared to contain the distilled water instead of the sample. Absorbances were recorded using a JENWAY 6305UV/Vis spectrophotometer (Jenway® Equipment for Analysis, Staffordshire, UK) at $740 \mathrm{~nm}$. The phenolic content in extracts was determined using gallic acid as a standard and presented as gallic acid equivalents per gram of dry extract (mg GAE/g dry extract).

\section{Determination of total flavonoid content}

Flavonoid contents of the samples were measured spectrophotometrically [Park et al., 1997] with slight modification. The reaction mixture contained $1.0 \mathrm{~mL}$ of the pear extract (in the concentration of $1 \mathrm{mg} / \mathrm{mL}$ ), $0.1 \mathrm{~mL}$ of $10 \% \mathrm{Al}\left(\mathrm{NO}_{3}\right)_{3} \times 9 \mathrm{H}_{2} \mathrm{O}, 0.1 \mathrm{~mL}$ of $1 \mathrm{M} \mathrm{CH}_{3} \mathrm{COOK}$, and $4.1 \mathrm{~mL}$ of $80 \%$ ethanol. Control was prepared using $96 \%$ ethanol instead of the extract, while $96 \%$ ethanol solution was used as blank. Absorbances were measured at $415 \mathrm{~nm}$ (JENWAY 6305UV/Vis spectrophotometer) after incubation for $40 \mathrm{~min}$ at room temperature. Sample flavonoid concentrations $(\mathrm{mg} / \mathrm{mL})$ were calculated using the standard curve equation, and expressed as quercetin equivalents per gram of dry extract (mg QE/g dry extract) from three measurements.

\section{HPLC analysis}

Phenolic compounds in the extracts were determined by comparing the retention times and absorption spectra (200-400 nm) of unknown peaks with those of pure standards (arbutin, rutin, chlorogenic acid, isoquercitrin, quercitrin, hyperosid, procyanidin $\mathrm{B}_{1}$, procyanidin $\mathrm{B}_{2}$ ) injected under the same conditions. The HPLC-DAD analysis was performed on an Agilent 1200 Series HPLC system (Agilent Technologies, Palo Alto, CA, USA) equipped with a Lichrospher ${ }^{\circledR} 100$ RP $18 \mathrm{e}$ column $(5 \mu \mathrm{m}, 250 \times 4$ mm, Agilent Technologies, Palo Alto, CA, USA). Mobile phase A was formic acid in water $(1 \%, v / v)$ and mobile phase $\mathrm{B}$ was acetonitrile. The concentration of injected extracts varied from 1.5 to $55 \mathrm{mg} / \mathrm{mL}$. The injection volume was $30 \mu \mathrm{L}$, and flow rate was $1 \mathrm{~mL} / \mathrm{min}$ with the gradient program as follows: $5-15 \% \mathrm{~B}$ 0-5 min, 15-20\% B 5-8 min, 20\% B 8-12 min, 20-30\% B 12-15 min, 30\% B 15-17 min, 30-35\% B 17-20 min, 35\% B 20-22 $\mathrm{min}, 35-100 \%$ B 22-25 min. Stop time of the analysis was $25 \mathrm{~min}$. The column temperature was kept at $25^{\circ} \mathrm{C}$ during



Pyrus communis L.

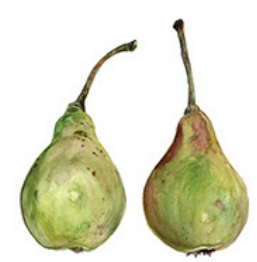

Vidovača

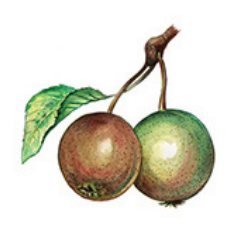

Takiša

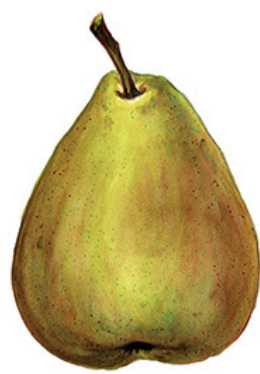

Lončara



Karamanka

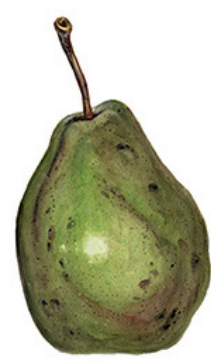

Jeribasma

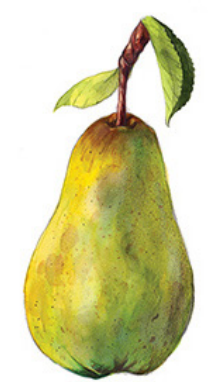

Williams Bartlett

FIGURE 1. Traditional pear varieties ('Vidovača', 'Lubeničarka', 'Karamanka', 'Jeribasma', 'Takiša', 'Lončara'), commercial variety ('Williams Bartlett') and wild pear. 
separation. The contents of individual phenolic compounds were expressed as $\mu \mathrm{g} / \mathrm{g}$ of dry extract. The samples were analyzed in triplicate [Šavikin et al., 2014].

\section{Evaluation of antioxidant activity}

\section{DPPH assay}

A slightly modified DPPH assay was employed [Blois, 1958] in order to evaluate free radical scavenging activity of the pear extracts. The reaction mixture $(2000 \mu \mathrm{L})$ containing the pear extract and methanolic solution of $\mathrm{DPPH}^{*}$ $(40 \mu \mathrm{g} / \mathrm{mL})$ was incubated in the dark at room temperature for $30 \mathrm{~min}$. Ascorbic acid, BHA, and BHT were used as positive controls (tested at the concentrations from $1-20 \mu \mathrm{g} / \mathrm{mL}$ ). The absorbances were measured using JENWAY 6305UV/Vis spectrophotometer at $517 \mathrm{~nm}$. Methanol was used as a blank, while control was prepared to contain methanol instead of the pear extract/standard. DPPH ${ }^{*}$ scavenging activity was determined using the following formula:

$\mathrm{DPPH} \cdot$ scavenging activity $(\%)=\left[\left(\mathrm{A}_{\mathrm{C}}-\mathrm{A}_{\mathrm{S}}\right) / \mathrm{A}_{\mathrm{C}}\right] \times 100 \%$

where: $A_{C}$ is absorbance of control and $A_{S}$ is absorbance of the reaction mixture. The results were presented as extract concentration providing $50 \%$ inhibition of $\mathrm{DPPH}^{\bullet}\left(\mathrm{IC}_{50}\right.$ value, $\mathrm{mg} / \mathrm{mL}$ ).

\section{ABTS assay}

ABTS assay [Miller et al., 1993] with slight modifications was also employed to evaluate radical scavenging activity of the pear extracts. ABTS ${ }^{*+}$ stock solution $(7 \mathrm{mM})$ in $2.46 \mathrm{mM}$ potassium-persulfate was prepared $12 \mathrm{~h}$ before experiment and stored at room temperature in the dark, and then subsequently diluted by distilled water to obtain a working solution which absorbance at $734 \mathrm{~nm}$ was $0.700 \pm 0.020$. The reaction mixture consisted of $50 \mu \mathrm{L}$ of extract $(1 \mathrm{mg} / \mathrm{mL})$ or methanolic solutions of BHA and BHT standards $(0.1 \mathrm{mg} / \mathrm{mL})$ and $2000 \mu \mathrm{L}$ of a working ABTS ${ }^{+}$ solution. Distilled water was used as a blank, while control contained distilled water instead of the sample. After incubation $\left(30 \mathrm{~min}\right.$ at $\left.30^{\circ} \mathrm{C}\right)$, absorbances were measured using the JENWAY $6305 \mathrm{UV} / \mathrm{Vis}$ spectrophotometer at $734 \mathrm{~nm}$. $\mathrm{ABTS}^{\bullet+}$ scavenging activity of the extracts was determined using ascorbic acid and presented as ascorbic acid equivalents (AAE) per gram of dry extract (mg AAE/g dry extract).

\section{Ferric-reducing antioxidant power (FRAP) assay}

In order to prepare FRAP reagent, sodium acetate buffer $(300 \mathrm{mM}, \mathrm{pH} 3.6)$, TPTZ $(10 \mathrm{mM})$ in $\mathrm{HCl}(40 \mathrm{mM})$ and $\mathrm{FeCl}_{3} \times 6 \mathrm{H}_{2} \mathrm{O}(20 \mathrm{mM})$ were mixed in the proportion of 10:1:1 $(\mathrm{v} / \mathrm{v} / \mathrm{v})$ and subsequently heated to $37^{\circ} \mathrm{C}$ before usage as previously described [Benzie \& Strain, 1996]. Pear extracts $(100 \mu \mathrm{L}$ in concentration of $1 \mathrm{mg} / \mathrm{mL})$ or positive controls (ascorbic acid, BHA, and BHT) in the concentration of $0.1 \mathrm{mg} / \mathrm{mL}$, were added to $3000 \mu \mathrm{L}$ of the FRAP reagent. After 4-min incubation at room temperature, absorbance of the reaction mixture was measured at $593 \mathrm{~nm}$ using the JENWAY 6305UV/Vis spectrophotometer. Distilled water was used as a blank, while control was prepared to contain distilled water instead of the sample. FRAP values were calculated using $\mathrm{FeSO}_{4} \times 7 \mathrm{H}_{2} \mathrm{O}$ standard curve and expressed as $\mu \mathrm{mol} F e($ II) $/ \mathrm{g}$ dry extract.

\section{Antineurodegenerative activity}

In the present study, AChE- and TYR-inhibitory effects of methanolic extracts of eight pear varieties were tested at concentrations of $25 \mu \mathrm{g} / \mathrm{mL}, 50 \mu \mathrm{g} / \mathrm{mL}$, and $100 \mu \mathrm{g} / \mathrm{mL}$.

\section{Inhibition of acethylcholinesterase activity}

Acethylcholinesterase (AChE) inhibition by the tested pear extracts was determined specrophotometrically using 96-well plates [Ellman et al., 1961]. The reaction mixture (S) was prepared to contain $140 \mu \mathrm{L}$ of a sodium phosphate buffer (0.1 M, pH 7.0), $20 \mu \mathrm{L}$ of DTNB, $20 \mu \mathrm{L}$ of a sample-buffer solution, and $20 \mu \mathrm{L}$ of an $\mathrm{AChE}$ solution ( 5 units $/ \mathrm{mL}$ ). The commercial AChE inhibitor, galanthamine, was used as a positive control. Control (C) contained sodium buffer instead of the test sample, while blank (B) did not contain AChE. The acetylthiocholine iodide solution $(10 \mu \mathrm{L})$ was added after incubation $\left(25^{\circ} \mathrm{C}, 15 \mathrm{~min}\right)$ to initiate the reaction. Absorbances were measured at $412 \mathrm{~nm}$ using a Tecan Sunrise SN microplate reader equipped with XFluor4 software (Tecan Group Ltd., Männedorf, Switzerland). The recorded absorbances were used to calculate the percentage of inhibition of $\mathrm{AChE}$ according to the formula:

AChE inhibition $(\%)=[\mathrm{C}-(\mathrm{S}-\mathrm{B}) / \mathrm{C}] \times 100$

\section{Inhibition of tyrosinase activity}

Inhibition of tyrosinase activity by the pear extracts was assessed spectrophotometrically using 96-well microtiter plates [Masuda et al., 2005]. The wells were designed as: A (containing $120 \mu \mathrm{L}$ of $0.1 \mathrm{M}$ sodium phosphate buffer, (pH 7) and $40 \mu \mathrm{L}$ of tyrosinase ( $46 \mathrm{U} / \mathrm{L}$ )), B (containing only phosphate buffer), $\mathrm{C}$ (containing $80 \mu \mathrm{L}$ of sodium phosphate buffer, $40 \mu \mathrm{L}$ of tyrosinase, and $40 \mu \mathrm{L}$ of the pear extract), and $\mathrm{D}$ (containing $120 \mu \mathrm{L}$ of phosphate buffer and $40 \mu \mathrm{L}$ of the pear extract). Subsequently, $40 \mu \mathrm{L}$ of L-DOPA was added and plates were incubated $\left(30 \mathrm{~min}, 25^{\circ} \mathrm{C}\right)$. Absorbances were measured at $475 \mathrm{~nm}$ using the Tecan Sunrise SN microplate reader equipped with XFluor4 software. Kojic acid was used as a positive control. The recorded absorbances were used to calculate the percentage of inhibition of TYR according to the formula:

TYR inhibition $(\%)=[(\mathrm{A}-\mathrm{B})-(\mathrm{C}-\mathrm{D}) /(\mathrm{A}-\mathrm{B})] \times 100 \%$

\section{Statistical analysis}

All measurements were performed in triplicate and presented as the mean \pm standard deviation. Analysis of variance (one-way ANOVA) and Tukey's post-hoc test were carried out to test the significance of differences among mean values using PAST (PAleontological STatistics) 3.21. [Hammer et al., 2001]. Pearson's correlation coefficients were calculated between the content of phenolic components and values obtained from different bioactivity assays [Taylor, 1990]. 


\section{RESULTS AND DISCUSSION}

\section{Extraction yield, and total phenolic and flavonoid} contents of the pear extracts

Extraction yield of mixed flesh and peel extracts varied from 7.63 to $13.5 \%$, that of flesh extracts from 7.40 to $15.7 \%$, while that of peel extracts between 8.60 and $13.0 \%$ (Table 1).

Total phenolic content (TPC) and total flavonoid content (TFC) of the methanolic extracts of peel, flesh, and mixed flesh and peel samples were evaluated applying frequently used colorimetric methods (Folin-Ciocalteu and $\mathrm{AlCl}_{3}$, respectively), which are described in literature in detail. The HPLC-DAD technique was subsequently employed for more precise quantitative-qualitative analysis of phenolic compounds.

The TPC and TFC of fruit extracts of eight pear varieties are presented in Table 1. The methanolic extracts obtained from peel, flesh, and mixed flesh and peel showed significantly $(p<0.05)$ different TPC and TFC for all tested pear varieties. Generally, the results showed that the traditional varieties 'Lončara' and 'Takiša' had the highest total phenolic contents, while 'Takiša' had the largest amount of total flavonoids.

TPC for the peel samples ranged from 10.7 to $272 \mathrm{mg}$ GAE/g dry extract for 'Lubeničarka' and 'Lončara' varieties, respectively. The TPC of flesh varied from $3.10 \mathrm{mg}$ GAE/g dry extract ('Lubeničarka') to $198 \mathrm{mg}$ GAE/g dry extract ('Lončara'). TPC of mixed flesh and peel extracts varied from 6.21 to $250 \mathrm{mg}$ GAE/g dry extract with extreme values for the same varieties as for both peel and flesh. The highest values of TPC in flesh and peel separately, and mixed flesh and peel were determined in the samples of traditional 'Lončara' and 'Takiša' varieties, while the lowest values in 'Lubeničarka' and 'Vidovača'. Comparing to the traditional varieties, TPC of wild pear and 'Williams Bartlett' displayed the intermediate values. A wide range of variations of TPC values was observed for the varieties analyzed in this study, as it was reported for other pear varieties of different origin [Kolniak-Ostek, 2016; Li et al., 2014].

Lower TPC of European pear fruit extract of $14.5 \mu \mathrm{g}$ GAE/g was achieved in the study of Sharma et al. [2015]. Abaci et al. [2016] investigated fruit of ten Turkish pear varieties and concluded that peel (300.1 to $687.2 \mathrm{mg} \mathrm{GAE} / 100 \mathrm{~g}$ ) had 2-3 times higher content of phenolic compounds than flesh (112.6 to $230.5 \mathrm{mg} \mathrm{GAE} / 100 \mathrm{~g}$ ). Kolniak-Ostek [2016] found that European pear peel (917.6 mg GAE/100 g dry matter) had 4 times higher amount of phenolics than flesh (234.2 mg GAE/100 g dry matter). Li et al. [2014] presented results of TPC determination in ten Chinese pear varieties and showed it was higher in the peel (263.6 to $1121.5 \mathrm{mg} \mathrm{GAE} / 100 \mathrm{~g}$ dry weight) than in the flesh. In our study, peel was 2-3 times, or even 5 times richer in TPC than flesh, ranging overall from $3.10 \mathrm{mg}$ GAE/g dry extract (flesh of 'Lubeničarka') to $272 \mathrm{mg}$ GAE/g dry extract (peel of 'Lončara'). Imeh \& Khohar [2002] reported the results of TPC determination in fruits of four commercial pear varieties (1795 to $2566 \mathrm{mg}$ GAE/100 g dry weight), which displayed similar amounts as apple fruit of commercial varieties.

The TFC of eight pear peel extracts ranged from 2.52 to $9.94 \mathrm{mg}$ QE/g dry extract with the lowest and the highest values determined for 'Vidovača' and 'Takiša', respectively.
TABLE 1. Extraction yield, total phenolic content (TPC), and total flavonoid content (TFC) of methanolic extracts of pear varieties.

\begin{tabular}{|c|c|c|c|c|}
\hline Variety & $\begin{array}{l}\text { Fruit } \\
\text { part }\end{array}$ & $\begin{array}{c}\text { Yield } \\
(\%)\end{array}$ & $\begin{array}{c}\text { TPC } \\
\text { (mg GAE/g } \\
\text { dry extract) }\end{array}$ & $\begin{array}{c}\text { TFC } \\
\text { (mg QE/g } \\
\text { dry extract) }\end{array}$ \\
\hline \multirow{3}{*}{ Wild pear } & flesh+peel & 12.3 & $16.4 \pm 0.5^{\mathrm{y}, \mathrm{c}}$ & $2.54 \pm 0.10^{\mathrm{y}, \mathrm{b}}$ \\
\hline & flesh & 12.0 & $13.3 \pm 0.2^{\mathrm{z}, \mathrm{c}}$ & $1.93 \pm 0.19^{\mathrm{z}, \mathrm{b}}$ \\
\hline & peel & 9.00 & $27.3 \pm 0.4^{\mathrm{x}, \mathrm{c}}$ & $4.82 \pm 0.30^{\mathrm{x}, \mathrm{b}}$ \\
\hline \multirow{3}{*}{ Takiša } & flesh+peel & 7.63 & $94.4 \pm 4.0^{y, b}$ & $6.03 \pm 0.18^{\mathrm{y}, \mathrm{a}}$ \\
\hline & flesh & 7.40 & $79.5 \pm 2.1^{z, b}$ & $3.21 \pm 0.20^{\mathrm{zaa}}$ \\
\hline & peel & 9.20 & $242 \pm 6^{x, b}$ & $9.94 \pm 0.19^{\mathrm{x}, \mathrm{a}}$ \\
\hline \multirow{3}{*}{ Lončara } & flesh+peel & 13.0 & $250 \pm 7^{y, a}$ & $1.83 \pm 0.11^{\mathrm{y}, \mathrm{c}}$ \\
\hline & flesh & 8.40 & $198 \pm 7$ z,a & $0.69 \pm 0.05^{\mathrm{z}, \mathrm{d}}$ \\
\hline & peel & 10.9 & $272 \pm 4^{\mathrm{x}, \mathrm{a}}$ & $3.16 \pm 0.15^{x, d}$ \\
\hline \multirow{3}{*}{ Jeribasma } & flesh+peel & 9.10 & $10.1 \pm 0.1^{\mathrm{y}, \mathrm{d}}$ & $1.36 \pm 0.07^{\mathrm{y}, \mathrm{d}}$ \\
\hline & flesh & 12.1 & $3.78 \pm 0.05^{\mathrm{z}, \mathrm{d}}$ & $1.22 \pm 0.09^{\mathrm{y}, \mathrm{c}}$ \\
\hline & peel & 8.60 & $23.2 \pm 0.7^{\mathrm{x}, \mathrm{c}}$ & $2.73 \pm 0.13^{x, d e}$ \\
\hline \multirow{3}{*}{ Vidovača } & flesh+peel & 11.1 & $6.56 \pm 0.33^{y, d}$ & $1.87 \pm 0.11^{\mathrm{y}, \mathrm{c}}$ \\
\hline & flesh & 15.7 & $5.39 \pm 0.06^{\mathrm{z}, \mathrm{d}}$ & $1.32 \pm 0.08^{\mathrm{z}, \mathrm{c}}$ \\
\hline & peel & 12.7 & $14.4 \pm 0.1^{\mathrm{x}, \mathrm{d}}$ & $2.52 \pm 0.07^{\mathrm{x}, \mathrm{e}}$ \\
\hline \multirow{3}{*}{ Lubeničarka } & flesh+peel & 13.5 & $6.21 \pm 0.09^{\mathrm{y}, \mathrm{d}}$ & $2.69 \pm 0.16^{\mathrm{y}, \mathrm{b}}$ \\
\hline & flesh & 9.52 & $3.10 \pm 0.02^{\mathrm{z}, \mathrm{d}}$ & $1.72 \pm 0.01^{\mathrm{z}, \mathrm{b}}$ \\
\hline & peel & 11.3 & $10.7 \pm 0.1^{\mathrm{x}, \mathrm{d}}$ & $4.30 \pm 0.09^{\mathrm{x}, \mathrm{c}}$ \\
\hline \multirow{3}{*}{ Karamanka } & flesh+peel & 11.4 & $8.45 \pm 0.49^{\mathrm{y}, \mathrm{cd}}$ & $0.98 \pm 0.03^{\mathrm{y} \text {,de }}$ \\
\hline & flesh & 11.3 & $4.51 \pm 0.24^{\mathrm{z}, \mathrm{d}}$ & $0.46 \pm 0.06^{\mathrm{z}, \mathrm{d}}$ \\
\hline & peel & 13.0 & $21.1 \pm 0.9^{\mathrm{x}, \mathrm{cd}}$ & $2.98 \pm 0.19^{\mathrm{x}, \mathrm{de}}$ \\
\hline \multirow{3}{*}{$\begin{array}{l}\text { Williams } \\
\text { Bartlett }\end{array}$} & flesh+peel & 9.40 & $10.1 \pm 0.1^{\mathrm{y}, \mathrm{cd}}$ & $1.07 \pm 0.83^{y, d}$ \\
\hline & flesh & 10.7 & $3.78 \pm 0.05^{\mathrm{z,d}}$ & $0.70 \pm 0.00^{\mathrm{z}, \mathrm{d}}$ \\
\hline & peel & 10.9 & $23.2 \pm 0.7^{\mathrm{x}, \mathrm{c}}$ & $2.57 \pm 0.10^{\mathrm{x}, \mathrm{e}}$ \\
\hline
\end{tabular}

Within each pear variety, mean values with different superscript letters $(x-z)$ differ significantly; for each fruit part separately, mean values with different superscript letters ${ }^{\text {(a-e) }}$ differ significantly between varieties (one-way ANOVA, Tukey's post hoc; $\mathrm{p}<0.05$ ). The superscript letters are assigned to show values in the descending order, where ${ }^{(\mathrm{x})}$ and $^{(\mathrm{a})}$ present the highest values. GAE - gallic acid equivalents; QE - quercetin equivalents.

TFC of the flesh extracts ranged from 0.46 to $3.21 \mathrm{mg} \mathrm{QE} / \mathrm{g}$ dry extract for 'Karamanka' to 'Takiša', and that of the mixed flesh and peel extracts ranged from 0.98 to $6.03 \mathrm{mg} \mathrm{QE} / \mathrm{g}$ dry extract with the extreme values noted for the same varieties. Li et al. [2014] analyzed TFC of ten pear fruit extracts of Chinese varieties and results showed that TFC was 6-20 times higher in the peel (281.2 to $1682.7 \mathrm{mg}$ rutin/100 g) than in the flesh. In turn, Sharma et al. [2015] recorded $10.30 \mu \mathrm{g}$ catechin equivalents/mg in the sample of European pear fruit extract. As many researchers reported, pears contain high amounts of phenolics, including flavonoids, in the whole fruit, flesh, and especially in the peel. Brahem et al. [2017] presented the phenolic profile of peel and flesh crude extracts, and noted 
TABLE 2. Content of individual phenolics in methanolic extracts of pear varieties ( $\mu \mathrm{g} / \mathrm{g}$ dry extract).

\begin{tabular}{|c|c|c|c|c|c|c|c|c|c|}
\hline Variety & $\begin{array}{l}\text { Fruit } \\
\text { part }\end{array}$ & Arbutin & \begin{tabular}{|c|}
$\begin{array}{c}\text { Chlorogenic } \\
\text { acid }\end{array}$ \\
\end{tabular} & Rutin & Hyperoside & Isoquercitrin & Quercitrin & \begin{tabular}{|c|} 
Procyanidin \\
$\mathrm{B}_{\perp}$ \\
\end{tabular} & $\begin{array}{c}\text { Procyanidin } \\
\mathrm{B}_{2} \\
\end{array}$ \\
\hline \multirow{3}{*}{ Wild pear } & flesh + peel & $485 \pm 20^{z . b}$ & $221 \pm 10^{\mathrm{x}, \mathrm{d}}$ & $\operatorname{tr}$ & $\operatorname{tr}$ & $20.7 \pm 5.05^{y, \mathrm{c}}$ & $100 \pm 6^{y, d}$ & $950 \pm 40^{\mathrm{x}, \mathrm{a}}$ & $213 \pm 10^{z, b}$ \\
\hline & flesh & $695 \pm 31^{x, b}$ & $61.2 \pm 4.8^{y, c}$ & $\operatorname{tr}$ & $\operatorname{tr}$ & $8.01 \pm 1.03^{z, b}$ & $92.8 \pm 4.6^{\mathrm{y}, \mathrm{c}}$ & $972 \pm 58^{\mathrm{x}, \mathrm{a}}$ & $275 \pm 14^{\mathrm{x}, \mathrm{b}}$ \\
\hline & peel & $555 \pm 29^{y, c}$ & $25.8 \pm 4.0^{\mathrm{z}, \mathrm{e}}$ & $\operatorname{tr}$ & $38.4 \pm 2.1^{\mathrm{c}}$ & $125 \pm 7^{\mathrm{x}, \mathrm{d}}$ & $264 \pm 13^{x, e}$ & $258 \pm 10^{\mathrm{y}, \mathrm{a}}$ & $245 \pm 11^{\mathrm{y}, \mathrm{b}}$ \\
\hline \multirow{3}{*}{ Takiša } & flesh+peel & $1708 \pm 62^{y, a}$ & $11763 \pm 63^{\text {ya }}$ & $\operatorname{tr}$ & $5820 \pm 76$ & $12216 \pm 46^{x, a}$ & $\operatorname{tr}$ & $671 \pm 30^{\mathrm{x}, \mathrm{b}}$ & $2065 \pm 62^{x, a}$ \\
\hline & flesh & $1157 \pm 44^{z, a}$ & $10795 \pm 49^{z, a}$ & $\operatorname{tr}$ & $\operatorname{tr}$ & $72.8 \pm 4.4^{\mathrm{z}, \mathrm{a}}$ & nd & $476 \pm 29^{\mathrm{y}, \mathrm{b}}$ & $393 \pm 17$ y,a \\
\hline & peel & $3749 \pm 72^{\mathrm{x}, \mathrm{a}}$ & $16147 \pm 60^{\mathrm{x}, \mathrm{a}}$ & $104 \pm 6^{c}$ & $215 \pm 10^{\mathrm{a}}$ & $657 \pm 21^{\mathrm{y}, \mathrm{a}}$ & $\operatorname{tr}$ & $161 \pm 4^{z, b}$ & $276 \pm 10^{\mathrm{z}, \mathrm{b}}$ \\
\hline \multirow{3}{*}{ Lončara } & flesh+peel & $114 \pm 5^{y, d}$ & $957 \pm 39^{\mathrm{y}, \mathrm{b}}$ & $\operatorname{tr}$ & $\operatorname{tr}$ & $10.1 \pm 1.0^{\mathrm{y}, \mathrm{c}}$ & $77.6 \pm 3.0^{\mathrm{e}}$ & $63.3 \pm 2.4^{y, c d}$ & $85.4 \pm 4.5^{z, c}$ \\
\hline & flesh & $100 \pm 5^{y, c d e}$ & $890 \pm 40^{\mathrm{y}, \mathrm{b}}$ & $\operatorname{tr}$ & $\operatorname{tr}$ & $1.70 \pm 0.30^{\mathrm{yd}}$ & $\operatorname{tr}$ & $50.1 \pm 2.1^{y, c}$ & $134 \pm 6^{y, c}$ \\
\hline & peel & $767 \pm 21^{x, b}$ & $1108 \pm 44^{x, b}$ & $84.9 \pm 4.0^{\mathrm{cd}}$ & $118 \pm 6^{\mathrm{b}}$ & $216 \pm 9^{\mathrm{x}, \mathrm{c}}$ & $275 \pm 11^{\mathrm{e}}$ & $296 \pm 13^{\mathrm{x}, \mathrm{a}}$ & $576 \pm 25^{x, a}$ \\
\hline \multirow{3}{*}{ Jeribasma } & flesh+peel & $17.6 \pm 1^{z, e}$ & $25.3 \pm 2.1^{\mathrm{z}, \mathrm{f}}$ & $24.2 \pm 1.1$ & $\operatorname{tr}$ & $3.55 \pm 0.21^{\mathrm{c}}$ & $264 \pm 12^{\mathrm{y}, \mathrm{a}}$ & $40.9 \pm 3.0^{\mathrm{z,d}}$ & $86.1 \pm 3.5^{y, c}$ \\
\hline & flesh & $122 \pm 7^{\mathrm{x}, \mathrm{cd}}$ & $36.3 \pm 2.9^{y, c}$ & $\operatorname{tr}$ & $\operatorname{tr}$ & $\operatorname{tr}$ & $70.7 \pm 3.7^{z, d}$ & $55.5 \pm 2.4^{y, c}$ & $93.3 \pm 4.0^{y, d}$ \\
\hline & peel & $60.9 \pm 2.9^{y, f}$ & $80.1 \pm 3.7^{x, e}$ & $571 \pm 25^{\mathrm{a}}$ & $\operatorname{tr}$ & $93.8 \pm 3.4^{\mathrm{f}}$ & $1778 \pm 48^{x, a}$ & $76.1 \pm 3.4^{\mathrm{x}, \mathrm{c}}$ & $175 \pm 6^{x, c}$ \\
\hline \multirow{3}{*}{ Vidovača } & flesh+peel & $175 \pm 6^{y, c d}$ & $27.1 \pm 1.7^{\mathrm{y}, \mathrm{f}}$ & $\operatorname{tr}$ & $\operatorname{tr}$ & $36.3 \pm 1.0^{y, c}$ & $145 \pm 3^{z, c}$ & $37.0 \pm 15.2^{\mathrm{d}}$ & $25.1 \pm 1.1^{\mathrm{z}, \mathrm{c}}$ \\
\hline & flesh & $104 \pm 5^{\mathrm{z}, \mathrm{cde}}$ & $37.5 \pm 2.0^{\mathrm{x}, \mathrm{c}}$ & $\operatorname{tr}$ & $\operatorname{tr}$ & $2.15 \pm 0.21^{z, d}$ & $192 \pm 7^{\text {y,a }}$ & nd & $110 \pm 5^{y, c d}$ \\
\hline & peel & $374 \pm 14^{x, d}$ & $30.2 \pm 1.1^{y, e}$ & $43.6 \pm 1.6^{c}$ & $\operatorname{tr}$ & $134 \pm 4^{\mathrm{x}, \mathrm{d}}$ & $376 \pm 12^{x, d}$ & $40.7 \pm 2.2^{\mathrm{d}}$ & $169 \pm 5^{x, c}$ \\
\hline \multirow{3}{*}{ Lubeničarka } & flesh+peel & $86.9 \pm 3.8^{\mathrm{z}, \mathrm{de}}$ & $62.6 \pm 3.1^{y}$ & $\operatorname{tr}$ & $0.10 \pm 0.03$ & $191 \pm 8^{x, c}$ & $108 \pm 4^{\mathrm{y}, \mathrm{d}}$ & $101 \pm 3^{y, c}$ & $52.0 \pm 1.3^{\mathrm{z}, \mathrm{c}}$ \\
\hline & flesh & $141 \pm 5^{y, c}$ & $64.4 \pm 2.9^{\mathrm{y}, \mathrm{c}}$ & $\operatorname{tr}$ & $\operatorname{tr}$ & $14.4 \pm 0.7^{\mathrm{z}, \mathrm{c}}$ & $95.1 \pm 3.0^{z, c}$ & $105 \pm 4^{y, c}$ & $76.0 \pm 2.8^{y, d}$ \\
\hline & peel & $308 \pm 13^{x, \mathrm{de}}$ & $88.4 \pm 4.0^{\mathrm{x}, \mathrm{e}}$ & $\operatorname{tr}$ & $38.3 \pm 1.9^{c}$ & $80.7 \pm 3.2^{\mathrm{y}, \mathrm{f}}$ & $131 \pm 5^{\mathrm{x}, \mathrm{f}}$ & $150 \pm 6^{x, b}$ & $99.2 \pm 3.3^{x, c}$ \\
\hline \multirow{3}{*}{ Karamanka } & flesh+peel & $84.3 \pm 3.3^{\mathrm{y} \text { de }}$ & $116 \pm 6^{y, e}$ & $\operatorname{tr}$ & $\operatorname{tr}$ & $20.0 \pm 1.1^{\mathrm{c}}$ & $210 \pm 8^{y, b}$ & $\operatorname{tr}$ & $\operatorname{tr}$ \\
\hline & flesh & $71.9 \pm 3.0^{\mathrm{y}, \mathrm{de}}$ & $92.9 \pm 3.7^{\mathrm{z}, \mathrm{c}}$ & $\operatorname{tr}$ & nd & $\operatorname{tr}$ & $134 \pm 6^{\mathrm{z}, \mathrm{b}}$ & $\operatorname{tr}$ & $\operatorname{tr}$ \\
\hline & peel & $247 \pm 8^{x, e}$ & $395 \pm 15^{\mathrm{x}, \mathrm{d}}$ & $367 \pm 13^{\mathrm{b}}$ & $\operatorname{tr}$ & $276 \pm 10^{\mathrm{b}}$ & $829 \pm 36^{x, b}$ & $\operatorname{tr}$ & $\operatorname{tr}$ \\
\hline \multirow{3}{*}{$\begin{array}{l}\text { Williams } \\
\text { Bartlett }\end{array}$} & flesh + peel & $226 \pm 10^{y, c}$ & $356 \pm 12^{y, c}$ & $\operatorname{tr}$ & $\operatorname{tr}$ & $36.9 \pm 2.7^{c}$ & $266 \pm 10^{\mathrm{a}}$ & $\operatorname{tr}$ & $\operatorname{tr}$ \\
\hline & flesh & $64.4 \pm 2.5^{z, e}$ & $38.6 \pm 2.8^{z, c}$ & $\operatorname{tr}$ & $\operatorname{tr}$ & $\operatorname{tr}$ & $\operatorname{tr}$ & $\operatorname{tr}$ & $\operatorname{tr}$ \\
\hline & peel & $710 \pm 21^{x, b}$ & $883 \pm 22^{x, c}$ & $49.4 \pm 2.7^{c}$ & $\operatorname{tr}$ & $81.0 \pm 3.2^{\mathrm{f}}$ & $463 \pm 20^{c}$ & $\operatorname{tr}$ & $\operatorname{tr}$ \\
\hline
\end{tabular}

Within each pear variety, mean values with different superscript letters ${ }^{(x-2)}$ differ significantly; for each fruit part separately, mean values with different superscript letters ${ }^{(a-f)}$ differ significantly between varieties (one-way ANOVA, Tukey's post hoc; $p<0.05$ ). The superscript letters are assigned to show values in the descending order, where ${ }^{(x)}$ and ${ }^{(a)}$ present the highest values. $\operatorname{tr}$ - traces, nd - not detected.

a higher phenolic content in the peel than in the flesh of pear fruit. In the mentioned studies, the TPC and TFC were measured predominantly in methanolic extracts, and varied depending on species or variety and employed methods of extraction.

The TPC and TFC values determined in the peel of all pear varieties were higher than those found in the flesh and mixed peel and flesh, which could be important data for the consumption of the fruits, because the peel is often discarded, resulting in the loss of valuable compounds [Abaci et al., 2016; Kolniak-Ostek, 2016; Lin \& Harnly, 2008; Öztürk et al., 2015].

\section{Phenolic composition of pear extracts}

Determination of the qualitative and quantitative composition of phenolics of the extracts of eight pear varieties was performed using the HPLC technique and the results are presented in Table 2. Among the eight pear varieties, chlorogenic acid in the peel (25.8 to $16147 \mu \mathrm{g} / \mathrm{g}$ dry extract) and arbutin in the peel (122 to $3748 \mu \mathrm{g} / \mathrm{g}$ dry extract) were the major compounds, followed by quercitrin in the peel (131 to $1778 \mu \mathrm{g} / \mathrm{g}$ dry extract), and isoquercitrin (3.55 to $12216 \mu \mathrm{g} / \mathrm{g}$ dry extract) in the mixed flesh and peel extracts.

The peel of the most pear varieties had the higher content of chlorogenic acid compared to flesh, such as those obtained from 'Takiša', 'Lončara' and 'Williams Bartlett'. In the previous study of eight Chinese pear varieties, chlorogenic acid content in the whole fruits varied between 10.3 and $263.8 \mu \mathrm{g} / \mathrm{g}$ [Li et al., 2012], while in our study the range was notably wider. Other varieties showed a high chlorogenic acid content in the peel; however, with the content differing among the analyzed varieties [Li et al., 2014; Salta et al., 2010]. As a potential chemoprotective agent, chlorogenic acid has been reported to elicit antioxidant, antitumor, and immune system-enhancing effects [Li et al., 2014]. 
The content of arbutin in the pear methanol extracts varied, being predominantly higher in the peel compared to the flesh (except for wild pear), ranging from 60.9 to $3749 \mu \mathrm{g} / \mathrm{g}$ dry extract of peel; from 64.4 to $1157 \mu \mathrm{g} / \mathrm{g}$ dry extract of flesh; and from 17.6 to $1708 \mu \mathrm{g} / \mathrm{g}$ dry extract of the mixed flesh and peel. The highest content of arbutin was detected in 'Takiša' variety, while the lowest one in 'Jeribasma'. In the previous studies, some pear varieties showed arbutin contents 2 to 3 times higher in the peel than in the flesh [Kolniak-Ostek, 2016; Li et al., 2014; Salta et al., 2010]. As the major phenolic compound found in the different parts of plant and fruit, arbutin exhibits strong free radical scavenging properties. Additionally, it has been proved to elicit antibacterial, anti-inflammatory, antitussive, and skin-whitening effects and to be effective against urinary infections [Li et al., 2014]. Dadgar et al. [2018] also demonstrated its ability to reduce oxidative stress in Parkinson's disease animal model.

In the present study, the contents of isoquercitrin, quercitrin, procyanidin $\mathrm{B}_{1}$, and procyanidin $\mathrm{B}_{2}$ differed depending on the variety and a fruit part used, with higher values determined in the peel. Quercitrin and isoquercitrin have been also identified in pears in some previous studies, which showed that their content varied greatly among cultivars and within different tissues [Liaudanskas et al., 2017]. Kaur \& Arya [2012] identified quercitrin and isoquercitrin in Pyrus communis, while in this study, quercitrin was found in the highest amount in 'Jeribasma' peel extract and isoquercitrin in mixed flesh and peel extract of 'Takiša'. Li et al. [2016a] compared the antioxidant effects of quercitrin and isoquercitrin and concluded that isoquercitrin exhibited higher reactive oxygen species (ROS) scavenging activity than quercitrin, protecting mesenchymal stem cells from ROS-induced oxidative damage. Jeong et al. [2017] isolated five proanthocyanidins from Pyrus pyrifolia peel, while in the current study procyanidin $\mathrm{B}_{2}$ was detected in the noticeably high amount in mixed flesh and peel extract of 'Takiša'. Fruits of wild pear were the richest in procyanidin $\mathrm{B}_{1}$.

Rutin and hyperoside were detected in traces in all pear varieties. Some natural polyphenolics, such as rutin, have been shown as potent inhibitors of COVID-19 main protease (Mpro), which is considered a potential therapeutic drug target [Adem et al., 2020].

Variations in the content of phenolics among different pear varieties were reported in the previous studies [Kolniak-Ostek et al., 2020; Li et al., 2014; Öztürk et al., 2015]. The content of individual phenolic compounds in the extracts varied widely among the tested varieties, which could be attributed to the sampling locality, different pre- or post-harvest conditions, or, as it was demonstrated for apple cultivars, genetics can be supposed to play a major role causing very high phenolic content variability [McClure et al., 2019]. Additionally, the phenolics are not equally distributed in the fruit [ $\mathrm{Li}$ et al., 2014].

Recent research indicates that long-term polyphenol consumption may play a vital role in promoting health through the regulation of metabolism and protection against various types of cancer, cardiovascular diseases, type 2 diabetes, gastrointestinal disorders, lung impairment, neurodegenerative diseases, etc. These benefits could be explained by the "biochemical scavenger theory", which suggests that phenolic compounds inactivate free radicals by forming stabilized chemical complexes, thus preventing further adverse reactions in the body [Cory et al., 2018].

The next step of the study was to investigate the antioxidant activity of the extracts and their potential to inhibit the enzymes involved in oxidative stress-induced neurodegenerative disorders.

\section{Antioxidant activity of pear extracts}

Three different assays: DPPH, ABTS and FRAP, were used to achieve more complete evaluation of the antioxidant activity of peel, flesh, and mixed peel and flesh fruit extracts. The results are presented in Table 3. In terms of the scavenging activity against $\mathrm{DPPH}^{\circ}$, all pear fruit extracts showed strong to low activity, depending on the variety. The DPPH' scavenging activity was as follows: 'Takiša' $>$ wild pear $>$ 'Lončara' > 'Vidovača' > 'Jeribasma' > 'Lubeničarka' > 'Karamanka' > 'Williams Bartlett'. The peel showed the highest DPPH' scavenging activity $\left(\mathrm{IC}_{50}\right.$ values ranging from 0.37 to $5.50 \mathrm{mg} / \mathrm{mL}$ ). With some exceptions, methanolic extracts obtained from peel, flesh, and mixed flesh and peel showed significantly different $\mathrm{IC}_{50}$ values for all tested pear varieties (Table 3). The highest antioxidant potential was determined in the peel of 'Takiša' $\left(\mathrm{IC}_{50}=0.37 \mathrm{mg} / \mathrm{mL}\right)$, followed by wild pear peel $\left(\mathrm{IC}_{50}=\right.$ $0.80 \mathrm{mg} / \mathrm{mL})$, and 'Lončara' peel $\left(\mathrm{IC}_{50}=1.56 \mathrm{mg} / \mathrm{mL}\right)$. In all samples, the mixture of flesh and peel showed intermediate activity $(0.79$ to $6.91 \mathrm{mg} / \mathrm{mL})$, while flesh extracts showed the lowest activity (3.71 to $22.39 \mathrm{mg} / \mathrm{mL}$ ). Compared to BHA and BHT standards and particularly ascorbic acid, the tested pear extracts showed notably lower DPPH ${ }^{*}$ scavenging activity.

Similar $\mathrm{DPPH}^{\bullet}$ scavenging activity to certain varieties in this study, was reported for the pear fruit extracts of some Chinese varieties [Li et al., 2012], i.e. Xuehua pear fruit $\left(\mathrm{IC}_{50}=0.59 \mathrm{mg} / \mathrm{mL}\right)$ and Nanguo pear fruit $\left(\mathrm{IC}_{50}=0.70 \mathrm{mg} / \mathrm{mL}\right)$. The extract of apple shaped pear ( $P$. pyrifolia var. pinggouli) showed $\mathrm{DPPH}^{*}$ scavenging activity expressed as $\mathrm{IC}_{50}=38.30 \mathrm{mg} / \mathrm{mL}$ [Ma et al., 2012], which is lower than the activity presented in this paper. Salta et al. [2010] investigated the scavenging activity of 'Rocha' pear fruit extract $\left(\mathrm{IC}_{50}=0.11 \mathrm{mg} / \mathrm{mL}\right)$ and also of a few commercial pear fruits, and obtained significantly higher antiradical activity against $\mathrm{DPPH}^{*}$ compared to results found in this research. Results of previous studies have indicated that pear fruit possesses a strong DPPH' antiradical potential, and that peel has a stronger antioxidant activity than flesh [Kolniak-Ostek, 2016; Li et al., 2012, 2014; Salta et al., 2010].

In the ABTS assay, the highest values were achieved for the peel extracts ( 1.17 to $2.91 \mathrm{mg}$ AAE/g dry extract); followed by mixed flesh and peel extracts ( 0.44 to $2.09 \mathrm{mg} \mathrm{AAE} / \mathrm{g}$ dry extract) and flesh ( 0.26 to $1.18 \mathrm{mg}$ AAE/g dry extract). For most of the tested pear varieties (Table 3), peel, flesh, and mixed flesh and peel methanolic extracts showed significantly $(\mathrm{p}<0.05)$ different antioxidant activities in the ABTS assay. The results obtained using this assay showed that 'Takiša' and 'Lončara' extracts exhibited the highest antioxidant activity. Compared to BHA and BHT standards, the tested extracts showed lower activity (Table 3 ). High ABTS ${ }^{\cdot+}$ scavenging activity of the European pear fruit methanolic extract $\left(\mathrm{IC}_{50}=15.90 \mathrm{mg}\right)$ was presented by Sharma et al. [2015]. 
TABLE 3. Antioxidant activity of methanolic extracts of pear varieties.

\begin{tabular}{|c|c|c|c|c|}
\hline $\begin{array}{l}\text { Variety/ } \\
\text { Standard }\end{array}$ & 壭 & 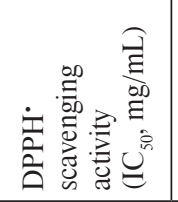 & 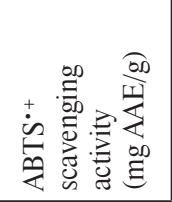 &  \\
\hline \multirow{3}{*}{ Wild pear } & flesh+peel & $2.85 \pm 0.19^{y, d}$ & $0.77 \pm 0.05^{\mathrm{y}, \mathrm{e}}$ & $743 \pm 19^{\text {y,a }}$ \\
\hline & flesh & $4.29 \pm 0.33^{x, d}$ & $0.76 \pm 0.07^{y, c}$ & $618 \pm 19^{\mathrm{z,a}}$ \\
\hline & peel & $0.80 \pm 0.05^{z, d}$ & $1.10 \pm 0.03^{\mathrm{x}, \mathrm{d}}$ & $880 \pm 21^{x, b}$ \\
\hline \multirow{3}{*}{ Takiša } & flesh+peel & $0.79 \pm 0.05^{y, e}$ & $1.54 \pm 0.09^{\mathrm{y}, \mathrm{b}}$ & $711 \pm 12^{\mathrm{y}, \mathrm{a}}$ \\
\hline & flesh & $3.85 \pm 0.23^{x, e}$ & $1.18 \pm 0.01^{z, b}$ & $606 \pm 8^{z, a}$ \\
\hline & peel & $0.37 \pm 0.03^{z, d}$ & $2.91 \pm 0.10^{\mathrm{x}, \mathrm{a}}$ & $933 \pm 22^{\mathrm{x}, \mathrm{a}}$ \\
\hline \multirow{3}{*}{ Lončara } & flesh+peel & $2.90 \pm 0.16^{\mathrm{yd}}$ & $2.09 \pm 0.10^{\mathrm{x}, \mathrm{a}}$ & $739 \pm 16^{\mathrm{y}, \mathrm{a}}$ \\
\hline & flesh & $3.71 \pm 0.14^{\mathrm{x}, \mathrm{e}}$ & $1.65 \pm 0.32^{x y, a}$ & $631 \pm 7^{z, a}$ \\
\hline & peel & $1.56 \pm 0.12^{z, c d}$ & $1.22 \pm 0.06^{y, d}$ & $882 \pm 23^{x, b}$ \\
\hline \multirow{3}{*}{ Jeribasma } & flesh+peel & $3.28 \pm 0.03^{x, d}$ & $0.44 \pm 0.03^{\mathrm{yf}}$ & $206 \pm 10^{y, d}$ \\
\hline & flesh & $3.71 \pm 0.07^{\mathrm{x}, \mathrm{e}}$ & $0.41 \pm 0.03^{y, d}$ & $190 \pm 9^{y, d}$ \\
\hline & peel & $2.72 \pm 0.09^{y, c}$ & $2.67 \pm 0.04^{\mathrm{x}, \mathrm{b}}$ & $737 \pm 14^{x, c}$ \\
\hline \multirow{3}{*}{ Vidovača } & flesh+peel & $6.91 \pm 0.25^{x, a}$ & $0.96 \pm 0.02^{\mathrm{y}, \mathrm{d}}$ & $409 \pm 13^{y, c}$ \\
\hline & flesh & $5.97 \pm 0.52^{\mathrm{x}, \mathrm{c}}$ & $0.59 \pm 0.03^{z, c d}$ & $330 \pm 8^{z, b}$ \\
\hline & peel & $2.28 \pm 0.68^{y, c}$ & $1.69 \pm 0.06^{x, c}$ & $647 \pm 2^{x, d}$ \\
\hline \multirow{3}{*}{ Lubeničarka } & flesh + peel & $4.99 \pm 0.07^{\mathrm{x}, \mathrm{c}}$ & $0.95 \pm 0.04^{\mathrm{y}, \mathrm{d}}$ & $393 \pm 18^{y, c}$ \\
\hline & flesh & $5.00 \pm 0.02^{\mathrm{x}, \mathrm{cd}}$ & $1.00 \pm 0.06^{\mathrm{y}, \mathrm{bc}}$ & $248 \pm 10^{z, c}$ \\
\hline & peel & $3.55 \pm 0.07 \mathrm{y}, \mathrm{b}$ & $1.17 \pm 0.03^{\mathrm{x}, \mathrm{d}}$ & $486 \pm 9^{x, e}$ \\
\hline \multirow{3}{*}{ Karamanka } & flesh+peel & $5.06 \pm 0.26^{y, \mathrm{c}}$ & $1.18 \pm 0.06^{\mathrm{ycc}}$ & $391 \pm 8^{y, c}$ \\
\hline & flesh & $11.4 \pm 0.7^{\mathrm{x}, \mathrm{b}}$ & $0.54 \pm 0.04^{z, c d}$ & $178 \pm 2^{z, d}$ \\
\hline & peel & $5.50 \pm 0.38^{\text {ya }}$ & $2.52 \pm 0.03^{\text {xab }}$ & $638 \pm 10^{\mathrm{x}, \mathrm{d}}$ \\
\hline \multirow{3}{*}{$\begin{array}{l}\text { Williams } \\
\text { Bartlett }\end{array}$} & flesh+peel & $5.96 \pm 0.40^{\mathrm{y}, \mathrm{b}}$ & $1.21 \pm 0.03^{y, c}$ & $456 \pm 4^{\mathrm{y}, \mathrm{b}}$ \\
\hline & flesh & $22.4 \pm 1.1^{\mathrm{x}, \mathrm{a}}$ & $0.26 \pm 0.04^{z, d}$ & $221 \pm 14^{z, c}$ \\
\hline & peel & $4.57 \pm 1.09^{\mathrm{y}, \mathrm{ab}}$ & $2.78 \pm 0.04^{\mathrm{x}, \mathrm{bc}}$ & $645 \pm 10^{\mathrm{x}, \mathrm{d}}$ \\
\hline \multicolumn{5}{|c|}{$\left(\mathrm{IC}_{50}, \mu \mathrm{g} / \mathrm{mL}\right)$} \\
\hline BHT & - & $17.9 \pm 0.2$ & $27.5 \pm 0.2$ & $4450 \pm 78$ \\
\hline BHA & - & $13.8 \pm 0.4$ & $28.2 \pm 0.1$ & $5840 \pm 53$ \\
\hline $\begin{array}{l}\text { Ascorbic } \\
\text { acid }\end{array}$ & - & $5.1 \pm 0.1$ & $\mathrm{nt}$ & $1810 \pm 86$ \\
\hline
\end{tabular}

Within each pear variety, mean values with different superscript letters ${ }^{(x-2)}$ differ significantly; for each fruit part separately, mean values with different superscript letters ${ }^{(a-e)}$ differ significantly between varieties (one-way ANOVA, Tukey's post hoc; $\mathrm{p}<0.05)$. The superscript letters are assigned to show values in the descending order, where ${ }^{(x)}$ and ${ }^{(a)}$ present the highest values. AAE - ascorbic acid equivalents, BHT - 3,5-di-tert-butyl-4-hydroxytoluene; BHA - 2(3)-tert-butyl-4-hydroxyanisole. nt - not tested.

Considering the FRAP assay results, the peel extracts showed significantly higher values than flesh, and flesh and peel ones. The FRAP values of the tested extracts were lower than those of the tested standards (Table 3). The highest
FRAP value was determined for the 'Takiša' peel extract $(933 \mu \mathrm{mol} \mathrm{Fe}(\mathrm{II}) / \mathrm{g}$ dry extract) followed by 'Lončara' peel extract $(882 \mu \mathrm{mol} \mathrm{Fe}(\mathrm{II}) / \mathrm{g}$ dry extract), and wild pear peel extract $(880 \mu \mathrm{mol} \mathrm{Fe}(\mathrm{II}) / \mathrm{g}$ dry extract). With exception of 'Jeribasma' extracts, all methanolic extracts obtained from peel, flesh, and mixed flesh and peel of all other varieites tested showed significantly different FRAP values (Table 3). The FRAP of four commercial pears showed similar values to commercial apple fruit varieties, and slightly higher ones compared to those reported for peach and kiwi fruits [Imeh \& Khokhar, 2012]. Kolniak-Ostek [2016] compared leaves, seeds, peel, and pulp of the 'Radana' pear and obtained the highest FRAP for leaves, probably because of the highest content of phenolics in this plant part.

To the best of our knowledge, there are a few studies on the ABTS and FRAP assays used to determine the antioxidant activity of pear fruits. However, due to the differences in the applied methods and presentation of results, it is difficult to directly compare our results with those obtained in other studies [Kolniak-Ostek, 2016; Kolniak-Ostek et al., 2020; Liaudanskas et al., 2017; Sharma et al., 2015].

The highest antioxidant activity of 'Takiša', especially of the outer part of the fruit, could be attributed to the highest content of detected phenolics, particularly chlorogenic acid which is known for its antioxidant potential [Li et al., 2014].

\section{Antineurodegenerative activity of pear extracts}

The results of the evaluation of the antineurodegenerative activities of pear extracts are presented in Table 4. The extracts did not show enzyme inhibitory activity in the concentrationdependent manner. Methanolic extracts obtained from peel, flesh, and mixed flesh and peel of the pear varieties tested, showed significantly different AChE- and TYR-inhibiting activities (Table 4). No correlation was established between inhibiting effects against both enzymes and fruit parts of all varieties.

The AChE inhibition by the tested extracts, compared to galanthamine (42.38 to $57.11 \%$ ), was low to moderate. The highest AChE inhibitory activity displayed mixed flesh and peel extracts of 'Lončara' (40.4\%) at $50 \mu \mathrm{g} / \mathrm{mL}$ and 'Takiša' (39.5\%) at $100 \mu \mathrm{g} / \mathrm{mL}$. In some cases, the mixed flesh and peel extracts ('Takiša', 'Lončara', 'Vidovača') showed higher AChE inhibitory activity than flesh or peel, but in some cases the peel extract showed the highest activity (wild pear).

The TYR inhibition by the studied extracts was lower than the inhibition displayed by kojic acid (33.93 to $51.81 \%$ ). The highest inhibition of TYR activity exhibited 'Takiša' peel extract $(32.8 \%)$ at the concentration of $50 \mu \mathrm{g} / \mathrm{mL}$, which is close to kojic acid at the same concentration.

Previous studies have shown the significant inhibition of AChE and TYR by various fruit extracts [Szwajgier \& Borowiec, 2012; Šavikin et al., 2018]. Antineurodegenerative activity of $70 \%$ ethanolic extract of peel of Punica granatum L. was studied by Šavikin et al. [2018], who obtained the highest AChE inhibition of $33.46 \%$ at extract concentration of $100 \mu \mathrm{g} / \mathrm{mL}$, which is moderate compared to galanthamine $(57.11 \%$ ), while TYR inhibitory activity of $78.46 \%$ was higher than the inhibition ensured by kojic acid (51.81\%). 
TABLE 4. Antineurodegenerative activities of methanolic extracts with different concentrations obtained from pear varieties.

\begin{tabular}{|c|c|c|c|c|c|c|c|}
\hline \multirow{2}{*}{$\begin{array}{l}\text { Variety/ } \\
\text { Standard }\end{array}$} & \multirow{2}{*}{ Fruit part } & \multicolumn{3}{|c|}{ AChE inhibition (\%) } & \multicolumn{3}{|c|}{ TYR inhibition (\%) } \\
\hline & & $25 \mu \mathrm{g} / \mathrm{mL}$ & $50 \mu \mathrm{g} / \mathrm{mL}$ & $100 \mu \mathrm{g} / \mathrm{mL}$ & $25 \mu \mathrm{g} / \mathrm{mL}$ & $50 \mu \mathrm{g} / \mathrm{mL}$ & $100 \mu \mathrm{g} / \mathrm{mL}$ \\
\hline \multirow{3}{*}{ Wild pear } & flesh + peel & $21.8 \pm 0.7^{y, a}$ & $34.5 \pm 3.0^{\mathrm{x}, \mathrm{b}}$ & $31.6 \pm 3.1^{x, b}$ & $17.7 \pm 1.4^{\mathrm{y}, \mathrm{c}}$ & $21.2 \pm 3.2^{\mathrm{y}, \mathrm{b}}$ & $13.4 \pm 0.8^{z, c}$ \\
\hline & flesh & $9.53 \pm 3.37^{z, d}$ & $36.9 \pm 0.4^{\mathrm{x}, \mathrm{a}}$ & $12.5 \pm 0.8^{\mathrm{y}, \mathrm{c}}$ & $17.8 \pm 2.1^{\mathrm{y}, \mathrm{b}}$ & $20.7 \pm 1.6^{\mathrm{y}, \mathrm{b}}$ & $23.7 \pm 2.2^{\mathrm{x}, \mathrm{a}}$ \\
\hline & peel & $34.7 \pm 2.43^{\mathrm{x}, \mathrm{a}}$ & $38.9 \pm 1.4^{\mathrm{x}, \mathrm{a}}$ & $32.4 \pm 2.6^{\mathrm{x}, \mathrm{ab}}$ & $24.6 \pm 1.8^{\mathrm{x}, \mathrm{a}}$ & $27.4 \pm 2.1^{\mathrm{x}, \mathrm{b}}$ & $19.4 \pm 1.8^{\mathrm{y}, \mathrm{ab}}$ \\
\hline \multirow{3}{*}{ Takiša } & flesh+peel & $30.1 \pm 2.7^{\mathrm{x}, \mathrm{a}}$ & $33.5 \pm 3.2^{\mathrm{x}, \mathrm{b}}$ & $39.5 \pm 2.4^{\mathrm{x}, \mathrm{a}}$ & $27.8 \pm 1.0^{x y, a}$ & $28.2 \pm 2.5^{\mathrm{xy}, \mathrm{a}}$ & $22.9 \pm 1.8^{\mathrm{x}, \mathrm{ab}}$ \\
\hline & flesh & $26.3 \pm 2.7^{\mathrm{x}, \mathrm{c}}$ & $34.4 \pm 1.5^{\mathrm{x}, \mathrm{a}}$ & $28.4 \pm 1.5^{\mathrm{y}, \mathrm{b}}$ & $29.2 \pm 2.7^{\mathrm{x}, \mathrm{a}}$ & $23.7 \pm 2.3^{\text {y.ab }}$ & $21.1 \pm 2.1^{\mathrm{x}, \mathrm{ab}}$ \\
\hline & peel & $7.10 \pm 0.91^{\mathrm{ye}}$ & $32.4 \pm 3.4^{\mathrm{x}, \mathrm{b}}$ & $9.19 \pm 0.94^{z, d}$ & $22.3 \pm 2.9^{\text {y.ab }}$ & $32.8 \pm 0.7^{\mathrm{x}, \mathrm{a}}$ & $24.6 \pm 2.8^{\mathrm{x}, \mathrm{a}}$ \\
\hline \multirow{3}{*}{ Lončara } & flesh+peel & $31.5 \pm 3.1^{\mathrm{x}, \mathrm{a}}$ & $40.4 \pm 0.9^{\mathrm{x}, \mathrm{a}}$ & $30.9 \pm 2.2^{\mathrm{x}, \mathrm{b}}$ & $24.5 \pm 2.1^{\mathrm{x}, \mathrm{ab}}$ & $21.1 \pm 1.8^{\mathrm{y}, \mathrm{b}}$ & $26.5 \pm 1.0^{\mathrm{x}, \mathrm{a}}$ \\
\hline & flesh & $31.3 \pm 1.0^{\mathrm{x}, \mathrm{b}}$ & $36.1 \pm 4.6^{x, a}$ & $35.7 \pm 4.5^{\mathrm{x}, \mathrm{a}}$ & $26.6 \pm 1.7^{\mathrm{x}, \mathrm{a}}$ & $27.0 \pm 1.9^{\mathrm{x}, \mathrm{a}}$ & $17.8 \pm 1.7^{y, b c}$ \\
\hline & peel & $29.4 \pm 0.4^{\mathrm{x}, \mathrm{b}}$ & $36.4 \pm 3.2^{\mathrm{x}, \mathrm{ab}}$ & $30.2 \pm 3.3^{\mathrm{x}, \mathrm{ab}}$ & $17.4 \pm 1.5^{\mathrm{y}, \mathrm{b}}$ & $21.8 \pm 0.8^{\mathrm{y}, \mathrm{c}}$ & $20.1 \pm 2.1^{y, a b}$ \\
\hline \multirow{3}{*}{ Jeribasma } & flesh + peel & $7.66 \pm 0.95^{\mathrm{y}, \mathrm{b}}$ & $36.3 \pm 0.6^{\mathrm{x}, \mathrm{a}}$ & $10.3 \pm 1.7^{\mathrm{z}, \mathrm{d}}$ & $22.8 \pm 1.6^{x, b}$ & $25.0 \pm 2.1^{\mathrm{x}, \mathrm{ab}}$ & $17.4 \pm 2.7^{\mathrm{x}, \mathrm{bc}}$ \\
\hline & flesh & $7.34 \pm 0.69^{\mathrm{y}, \mathrm{d}}$ & $7.92 \pm 1.0^{\mathrm{y}, \mathrm{b}}$ & $29.9 \pm 3.6^{6, a b}$ & $21.1 \pm 1.8^{\mathrm{x}, \mathrm{b}}$ & $11.8 \pm 0.5^{\mathrm{z}, \mathrm{d}}$ & $16.8 \pm 1.1^{\mathrm{xy}, \mathrm{bc}}$ \\
\hline & peel & $37.8 \pm 1.0^{\mathrm{x}, \mathrm{a}}$ & $35.6 \pm 2.6^{\mathrm{x}, \mathrm{ab}}$ & $24.0 \pm 0.1^{\mathrm{y}, \mathrm{bc}}$ & $18.5 \pm 2.2^{x, b}$ & $16.6 \pm 2.1^{\mathrm{y}, \mathrm{de}}$ & $12.7 \pm 1.1^{\mathrm{y}, \mathrm{c}}$ \\
\hline \multirow{3}{*}{ Vidovača } & flesh+peel & $27.7 \pm 1.8^{\mathrm{x}, \mathrm{a}}$ & $36.6 \pm 1.0^{\mathrm{x}, \mathrm{a}}$ & $24.9 \pm 0.3^{\mathrm{x}, \mathrm{c}}$ & $14.9 \pm 1.9^{y, \mathrm{~cd}}$ & $20.7 \pm 3.0^{\mathrm{xy}, \mathrm{b}}$ & $20.2 \pm 0.6^{x, b}$ \\
\hline & flesh & $8.47 \pm 0.44^{z, d}$ & $10.3 \pm 2.0^{\mathrm{y}, \mathrm{b}}$ & $27.6 \pm 1.7^{x, b}$ & $27.4 \pm 2.1^{\mathrm{x}, \mathrm{a}}$ & $27.1 \pm 2.4^{\mathrm{x}, \mathrm{a}}$ & $21.7 \pm 2.2^{\mathrm{x}, \mathrm{ab}}$ \\
\hline & peel & $12.6 \pm 0.3^{y, d}$ & $7.99 \pm 0.84^{\mathrm{y}, \mathrm{d}}$ & $20.5 \pm 0.8^{y, c}$ & $11.9 \pm 1.7^{\mathrm{y}, \mathrm{c}}$ & $15.0 \pm 2.3^{y, d e}$ & $23.9 \pm 2.0^{\mathrm{x}, \mathrm{a}}$ \\
\hline \multirow{3}{*}{ Lubeničarka } & flesh+peel & $35.0 \pm 0.8^{x, a}$ & $37.5 \pm 1.4^{\mathrm{x}, \mathrm{a}}$ & $24.2 \pm 0.8^{y, c}$ & $25.3 \pm 0.9^{\text {x.ab }}$ & $24.4 \pm 0.7^{\mathrm{x}, \mathrm{ab}}$ & $25.0 \pm 2.7^{\mathrm{x}, \mathrm{a}}$ \\
\hline & flesh & $37.4 \pm 1.8^{\mathrm{x}, \mathrm{a}}$ & $36.6 \pm 2.0^{\mathrm{x}, \mathrm{a}}$ & $35.2 \pm 3.3^{\mathrm{x}, \mathrm{a}}$ & $10.4 \pm 0.6^{\mathrm{z}, \mathrm{c}}$ & $13.2 \pm 0.6^{y, c d}$ & $16.5 \pm 0.7^{\mathrm{y}, \mathrm{bc}}$ \\
\hline & peel & $34.0 \pm 2.4^{\mathrm{x}, \mathrm{ab}}$ & $28.8 \pm 2.5^{\mathrm{y}, \mathrm{b}}$ & $28.7 \pm 1.8^{\mathrm{y}, \mathrm{bc}}$ & $20.4 \pm 2.1^{\text {y,ab }}$ & $13.7 \pm 1.0^{y, e}$ & $8.56 \pm 1.00^{z, c}$ \\
\hline \multirow{3}{*}{ Karamanka } & flesh + peel & $8.99 \pm 0.85^{\mathrm{y}, \mathrm{b}}$ & $9.83 \pm 0.67^{y, c}$ & $12.3 \pm 1.5^{y, d}$ & $17.4 \pm 2.1^{\mathrm{x}, \mathrm{c}}$ & $13.5 \pm 0.6^{z, c}$ & $9.80 \pm 1.12^{\mathrm{y}, \mathrm{d}}$ \\
\hline & flesh & $9.57 \pm 0.31^{\mathrm{y}, \mathrm{d}}$ & $10.7 \pm 1.1^{y, b}$ & $9.60 \pm 0.12^{y, c}$ & $18.7 \pm 1.9^{\mathrm{x}, \mathrm{b}}$ & $17.2 \pm 1.2^{\mathrm{y}, \mathrm{c}}$ & $16.5 \pm 1.3^{\mathrm{x}, \mathrm{bc}}$ \\
\hline & peel & $30.6 \pm 0.6^{x, b}$ & $34.5 \pm 1.2^{\mathrm{x}, \mathrm{ab}}$ & $36.7 \pm 2.1^{\mathrm{x}, \mathrm{a}}$ & $19.4 \pm 0.7^{7 \text {,ab }}$ & $25.6 \pm 1.0^{\mathrm{x}, \mathrm{bc}}$ & $14.8 \pm 0.8^{\mathrm{x}, \mathrm{bc}}$ \\
\hline \multirow{3}{*}{$\begin{array}{l}\text { Williams } \\
\text { Bartlett }\end{array}$} & flesh+peel & $9.56 \pm 0.82^{\mathrm{y}, \mathrm{b}}$ & $8.86 \pm 0.82^{\mathrm{y}, \mathrm{c}}$ & $20.1 \pm 2.5^{z, c}$ & $10.6 \pm 0.96^{\mathrm{y}, \mathrm{d}}$ & $13.0 \pm 1.9^{\mathrm{y}, \mathrm{c}}$ & $9.81 \pm 1.00^{\mathrm{y}, \mathrm{d}}$ \\
\hline & flesh & $23.8 \pm 2.9^{\mathrm{x}, \mathrm{c}}$ & $34.3 \pm 1.1^{\mathrm{x}, \mathrm{a}}$ & $39.4 \pm 1.1^{\mathrm{x}, \mathrm{a}}$ & $15.1 \pm 1.66^{\mathrm{x}, \mathrm{bc}}$ & $14.5 \pm 1.2^{\mathrm{xy}, \mathrm{cd}}$ & $14.8 \pm 1.9^{\mathrm{x}, \mathrm{c}}$ \\
\hline & peel & $23.4 \pm 0.9^{\mathrm{x}, \mathrm{c}}$ & $34.5 \pm 1.6^{\mathrm{x}, \mathrm{ab}}$ & $28.4 \pm 1.7 \mathrm{y}, \mathrm{bc}$ & $8.83 \pm 1.29 \mathrm{y}, \mathrm{c}$ & $18.5 \pm 1.9^{\mathrm{x}, \mathrm{d}}$ & $16.1 \pm 1.6^{\mathrm{x}, \mathrm{b}}$ \\
\hline Galanthamine & - & $42.4 \pm 0.7$ & $50.6 \pm 0.5$ & $57.1 \pm 1.7$ & - & - & - \\
\hline Kojic acid & - & - & - & - & $35.7 \pm 5.5$ & $33.9 \pm 3.8$ & $51.8 \pm 2.6$ \\
\hline
\end{tabular}

Within each pear variety, mean values with different superscript letters ${ }^{(x-z)}$ differ significantly; for each fruit part separately and each tested concentration, mean values with different superscript letters ${ }^{(a-e)}$ differ significantly between varieties (one-way ANOVA, Tukey's post hoc; $\mathrm{p}<0.05$ ). The superscript letters are assigned to show values in the descending order, where ${ }^{(x)}$ and ${ }^{(a)}$ present the highest values. GAE - gallic acid equivalents; AChE - acetylcholinesterase; TYR - tyrosinase.

Szwajgier \& Borowiec [2012] investigated anti-AChE activities of numerous fruits, and found significant activity of extracts of whole fruits, or juices. Peach juice (Prunus persica L.) and wild strawberry fruit extract (Fragaria vesca L.) showed the highest AChE inhibitory activity (6.10 eserine $\mu \mathrm{M})$, followed by apple juice varieties (Mallus domestica Borkh.) (2.91 to 6.10 eserine $\mu \mathrm{M}$ ), and plum extract (Prunus domestica L.) (3.09 eserine $\mu \mathrm{M})$. Their results proved that different fruits can be promising sources of inhibitors of enzymes implicated in neurodegeneration, potentially preventing Alzheimer's and Parkinson's diseases [Szwajgier \& Borowiec, 2012; Šavikin et al., 2018].

\section{Correlation among TPC, TFC, and individual phenolic compounds and bioactivity assays}

As presented in Table 5, results of ABTS and FRAP assays were moderately correlated with TPC and TFC. Results of those assays showed weak correlation to arbutin and chlorogenic acid, while rutin and quercitrin and $\mathrm{ABTS}^{\cdot+}$ scavenging activity were moderately correlated. A negative correlation was determined between $\mathrm{DPPH}^{\bullet}$ scavenging activity and TPC, TFC and phenolic constituents because of presenting results of DPPH assay using $\mathrm{IC}_{50}$ values. The results obtained by DPPH assay were moderately correlated to TPC, TFC, and arbutin content. AChE inhibitory activity showed 
TABLE 5. Correlation coefficients $(r)$ among total phenolic content (TPC), total flavonoid content (TFC), and individual phenolic compound contents and results of bioactivity assays.

\begin{tabular}{|c|c|c|c|c|c|}
\hline & 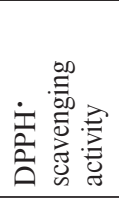 & 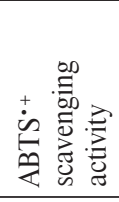 &  & 岂: & 总: \\
\hline ТPC & -0.36 & 0.39 & 0.52 & 0.34 & 0.46 \\
\hline TFC & -0.50 & 0.44 & 0.43 & 0.30 & 0.54 \\
\hline Arbutin & -0.36 & 0.36 & 0.29 & 0.17 & 0.53 \\
\hline $\begin{array}{l}\text { Chlorogenic } \\
\text { acid }\end{array}$ & -0.30 & 0.30 & 0.06 & 0.16 & 0.53 \\
\hline Rutin & -0.13 & 0.61 & 0.35 & 0.18 & 0.04 \\
\hline Hyperoside & -0.20 & 0.08 & -0.07 & 0.09 & 0.28 \\
\hline Isoquercitrin & -0.21 & 0.10 & -0.06 & 0.09 & 0.30 \\
\hline Quercitrin & -0.13 & 0.55 & 0.33 & 0.06 & -0.13 \\
\hline Procyanidin $\mathrm{B}_{1}$ & -0.29 & -0.16 & 0.26 & 0.33 & 0.23 \\
\hline Procyanidin $\mathrm{B}_{2}$ & -0.34 & 0.08 & 0.08 & 0.18 & 0.36 \\
\hline
\end{tabular}

According to Taylor (1990): $r \leq 0.35$ weak correlation; $0.36<r<0.67$ moderate correlation; $0.68<r<1$ strong correlation; AChE - acetylcholinesterase; TYR - tyrosinase.

weak correlation to TPC, TFC, and individual components. TYR inhibitory activity displayed moderate correlation to TPC, TFC, arbutin and chlorogenic acid contents. In some other studies of pear fruit extracts, peel-flesh phenolic content, peel phenolic content, and flesh phenolic content were significantly correlated [Abaci et al., 2016]. Many researchers have found that antioxidant capacity of pear fruit appears to be strongly influenced by TPC and TFC, and highly significant linear correlations were shown between phenolic contents and antioxidant capacity [Abaci et al., 2016; Imeh \& Khohar, 2002; Kolniak-Ostek, 2016; Kolniak-Ostek et al., 2020; Li et al., 2012, 2014; Öztürk et al., 2015; Salta et al., 2010; Sharma et al., 2016].

\section{CONCLUSION}

This study evaluated phenolic composition, total phenolic and flavonoid contents, and biological activities (antioxidant and antineurodegenerative) of peel, flesh, and mixed flesh and peel methanolic extracts of six traditional pear varieties ('Vidovača', 'Lubeničarka', 'Karamanka', 'Jeribasma', 'Takiša', 'Lončara'), one commercial variety ('Williams Bartlett'), and wild pear from Serbia. All varieties, as well as wild pear, were analyzed for the first time from this perspective. Methanolic extracts of traditional pear fruit varieties showed a high content of total phenolics and flavonoids, significant antioxidant potential, and moderate antineurodegenerative activity. The significant level of phenolics and flavonoids, and the highest antioxidant activity were shown by 'Takiša', 'Lončara', and 'Jeribasma'. Wild pear had average or high antioxidant activity, while commercial 'Williams
Bartlett' displayed average or lower activities compared to traditional pear varieties from Serbia.

This study revealed that the fruits of the investigated traditional pears are rich in bioactive components and can be used in nutrition, for possible medical applications, and to prevent diseases induced by oxidative stress. The results are important to enhance their production as a significant source of functional food and potential medicinal remedy. Because of vulnerability of the gene pool, it is necessary to preserve the traditional pear varieties, as a favorable way to increase health benefits and agriculture sustainability. In the food processing industry, it is essential to develop technologies that will enable to process food, in order to keep high nutritional quality, but, also to retain its functional properties and biological activity. The COVID-19 pandemic affects the whole food sector, including food safety, bioactive food ingredients, food security, and sustainability. One of the promising alternatives in post-pandemic world includes the development of nutritional and immune-boosting plant-based products which could support the human health [Galanakis et al., 2021].

\section{ACKNOWLEDGEMENT}

The authors are grateful to Bora Milićević for drawings of Pyrus varieties.

\section{RESEARCH FUNDING}

This manuscript was supported by the Ministry of Education, Science and Technological Development of the Republic of Serbia, Grants No 451-03-9/2021-14/200178, 451-03-9/2021-14/200003 and 451-03-9/2021-14/200007.

\section{CONFLICT OF INTEREST}

The authors declare no conflict of interest.

\section{ORCID IDs}

A. Alimpić Aradski https://orcid.org/0000-0002-0879-6467

S. Duletić-Laušević https://orcid.org/0000-0002-4777-3989

S. Jarić https://orcid.org/0000-0002-9356-7334

P.D. Marin https://orcid.org/0000-0002-9460-1012

A. Savić https://orcid.org/0000-0002-9106-9980

K. Šavikin https://orcid.org/0000-0002-2086-9593

J. Živković https://orcid.org/0000-0002-9684-2637

\section{REFERENCES}

1. Abaci, Z.T., Sevindik, E., Ayvaz, M. (2016). Comparative study of bioactive components in pear genotypes from Ardahan/Turkey. Biotechnology \& Biotechnological Equipment, 30, 36-43. https://doi.org/10.1080/13102818.2015.1095654

2. Adem, S., Eyupoglu, V., Sarfraz, I., Rasul, A., Ali, M. (2020). Identification of potent COVID-19 main protease (Mpro) inhibitors from natural polyphenols: An in silico strategy unveils a hope against CORONA. Preprints, art. no. 2020030333. https://doi.org/10.20944/preprints202003.0333.v1 
3. Benzie, I.F., Strain, J.J. (1996). The ferric reducing ability of plasma (FRAP) as a measure of antioxidant power: the FRAP assay. Analytical Biochemistry, 239, 70-76.

https://doi.org/10.1006/abio.1996.0292

4. Blois, M.S. (1958). Antioxidant determinations by the use of a stable free radical. Nature, 181, 1199-1200.

https://doi.org/10.1038/1811199a0

5. Brahem, M., Renard, C.M.G.C., Eder, S., Loonis, M., Ouni, R., Messaoud, M., Le Bourvellec, C. (2017). Characterization and quantification of fruit phenolic compounds of European and Tunisian pear cultivars. Food Research International, 95, 125-133.

https://doi.org/10.1016/j.foodres.2017.03.002

6. Carbonaro, M., Mattera, M., Nicoli, S., Bergamo, P., Cappelloni, M. (2002). Modulation of antioxidant compounds in organic vs conventional fruit (Peach, Prunus persica L., and Pear, Pyrus communis L.). Journal of Agricultural and Food Chemistry, 50, 5458-5462.

https://doi.org/10.1021/jf0202584

7. Chel-Guerrero L.D., Sauri-Duch E., Fragoso-Serrano M.C., Pérez-Flores L.J., Gómez-Olivares J.L., Salinas-Arreortu, N., Sierra-Palacios, E.C., Mendoza-Espinoza, J.A. (2018). Phytochemical profile, toxicity, and pharmacological potential of peels from four species of tropical fruits. Journal of Medicinal Food, 21(7), 734-743.

https://doi.org/10.1089/jmf.2017.0124

8. Cory, H., Passarelli, S., Szeto, J., Tamez, M., Mattei, J. (2018). The role of polyphenols in human health and food systems: A mini-review. Frontiers in Nutrition, 5, 87-96. https://doi.org/10.3389/fnut.2018.00087

9. Dadgar M., Pouramir, M., Dastan, Z., Ghasemi-Kasman, M., Ashrafpour, M., Moghadamnia, A.A., Khafri, S., Pourghasem, M. (2018). Arbutin attenuates behavioral impairment and oxidative stress in an animal model of Parkinson's disease. Avicenna Journal of Phytomedicine, 8, 533-542.

10. Dajić-Stevanović, Z., Petrović, M., Aćić, S. (2014). Ethnobotanical knowledge and traditional use of plants in Serbia in relation to sustainable rural development. In: Pieroni, A., Quave, C.L. (Eds.), Ethnobotany and Biocultural Diversities in the Balkans, Springer, New York, Heidelberg, Dordrecht, London, pp. 229-252. https://doi.org/10.1007/978-1-4939-1492-0_12

11. Ellman, G.L., Courtney, K.D., Andres, V., Featherstone, R.M. (1961). A new and rapid colorimetric determination of acetylcholinesterase activity. Biochemical Pharmacology, 7, 88-95. https://doi.org/10.1016/0006-2952(61)90145-9

12. Galanakis, C.M., Rizou, M., Aldawoud, T.M., Ucak, I., Rowan, N.J. (2021). Innovations and technology disruptions in the food sector within the COVID-19 pandemic and post-lockdown era. Trends in Food Science \& Technology, 110, 193-200. https://doi.org/10.1016/j.tifs.2021.02.002

13. Hammer, O., Harper, D.T., Ryan, P.D. (2001). PAST: Paleontological statistics software package for education and data analysis. Palaeontologia Electronica, 4, 1-9.

14. Imeh, U., Khokhar, S. (2002). Distribution of conjugated and free phenols in fruits. Journal of Agricultural and Food Chemistry, 50, 6301-6306.

https://doi.org/10.1021/jf020342j

15. Jeong, D.E., Cho, J.Y., Lee, Y.G., Jeong, H.Y., Lee, H.J., Moon, J.H. (2017). Isolation of five proanthocyanidins from pear (Pyrus pyrifolia Nakai) fruit peels. Food Science and Biotechnology, 26(5), 1209-1215.

https://doi.org/10.1007/s10068-017-0157-4

16. Kaur, R., Arya, V. (2012). Ethnomedicinal and phytochemical perspectives of Pyrus communis L. Journal of Pharmacognosy and Phytochemistry, 1, 14-19.

17. Kolniak-Ostek, J. (2016). Chemical composition and antioxidant capacity of different anatomical parts of pear (Pyrus communis L.). Food Chemistry, 203, 491-497. https://doi.org/10.1016/j.foodchem.2016.02.103

18. Kolniak-Ostek, J., Kłopotowska, D., Rutkowski, K.P., Skorupińska, A., Kruczyńska, D.E. (2020). Bioactive compounds and health-promoting properties of pear (Pyrus communis L.) fruits. Molecules, 25(19), art. no. 4444. https://doi.org/10.3390/molecules25194444

19. Li, X., Jiang, Q., Wang, T., Liu, J., Chen, D. (2016a). Comparison of the antioxidant effects of quercitrin and isoquercitrin: Understanding the role of the 6 "-OH group. Molecules, 21(9), 1246-1257.

https://doi.org/10.3390/molecules21091246

20. Li, X., Wang, T., Gao, W. (2016b). Nutritional composition of pear cultivars (Pyrus spp.). In V.R. Preedy, M.S.J. Simmonds (Eds.) Nutritional Composition of Fruit Cultivars, Academic Press, San Diego, CA, USA, pp. 573-608. https://doi.org/10.1016/B978-0-12-408117-8.00024-6

21. Li, X., Wang, T., Zhou, B., Gao, W., Cao, J., Huang, L. (2014). Chemical composition and antioxidant and anti-inflamatory potential of peels and flesh from 10 different pear varieties (Pyrus sp.). Food Chemistry, 152, 531-538. https://doi.org/10.1016/j.foodchem.2013.12.010

22. Li, X., Zhang, J.Y., Gao, V.V.Y., Wang, H.Y., Cao, J.G., Huang, L.Q. (2012). Chemical composition and anti-inflammatory and antioxidant activities of either pear cultivars. Journal of Agricultural and Food Chemistry, 60, 8738-8744.

https://doi.org/10.1021/jf303235h

23. Liaudanskas, M., Zymonè, K., Viškelis, J., Klevinskas, A., Janulis, V. (2017). Determination of the phenolic composition and antioxidant activity of pear extracts. Journal of Chemistry, 2017(1), 1-9. https://doi.org/10.1155/2017/7856521

24. Lin, L.Z., Harnly, J.M. (2008). Phenolic compounds and chromatographic profiles of pear skins (Pyrus spp.). Journal of Agricultural and Food Chemistry, 56, 9094-9101. https://doi.org/10.1021/jf8013487

25. Ma, J.-N.., Wang, S.-L., Zhang, K., Wu, Z.-G., Hattori, M., Chen, G.-L., Ma, C.-M. (2012). Chemical components and antioxidant activity of the peels of commercial apple shaped pear (fruit of Pyrus pyrifolia cv. pingguoli). Journal of Food Science, 77, C1097-C1102. https://doi.org/10.1111/j.1750-3841.2012.02899.x

26. Masuda, T., Yamashita, D., Takeda, Y., Yonemori, S. (2005). Screening for tyrosinase inhibitors among extracts of seashore plants and identification of potent inhibitors from Garcinia subelliptica. Bioscience, Biotechnology and Biochemistry, 69, 197-201. https://doi.org/10.1271/bbb.69.197

27. McClure, K.A., Gong, Y., Song, J., Vinqvist-Tymchuk, M., Palmer, L.C., Fan, L., Burgher-MacLellan, K., Zhang, Z.Q., Celton, J.M., Forney, C.F., Migicovsky, Z., Myles, S. (2019). Genome-wide association studies in apple reveal loci of large 
effect controlling apple polyphenols. Horticulture Research, 6(1), art. no. 107.

https://doi.org/10.1038/s41438-019-0190-y

28. Miller, N.J., Rice-Evans, C., Davies, M.J., Gopinathan, V., Milner, A. (1993). A novel method for measuring antioxidant capacity and its application to monitoring the antioxidant status in premature neonates. Clinical Science, 84, 407-412.

https://doi.org/10.1042/cs0840407

29. Öztürk, A., Demirsoy, L., Demirsoy, H., Asan, A., Gül, O. (2015). Phenolic compounds and chemical characteristics of pears (Pyrus communis L.). International Journal of Food Properties, 18, 536-546. https://doi.org/10.1080/10942912.2013.835821

30. Park, Y.K., Koo, M.H., Ikegaki, M., Contado, J.L. (1997). Comparison of the flavonoid aglycone contents of Apis melifera propolis from various regions of Brazil. Arquivos de Biologia e Tecnologia, 40, 97-106.

31. Parle, M., Arzoo, (2016). Why is pear so dear. International Journal of Research in Ayurveda and Pharmacy, 7, 108-113.

https://doi.org/10.7897/2277-4343.07139

32. Reiland, H., Slavin, J. (2015). Systematic review of pears and health. Food and Nutrition Today, 50(6), 301-305.

https://doi.org/10.1097/NT.0000000000000112

33. Salta, J, Martins, A., Santos, R.G., Neng, N.R., Nogneira, J.M.F., Justino, J., Ruter, A.P. (2010). Phenolic composition and antioxidant activity of Rocha pear and other pear cultivars - a comparative study. Journal of Functional Foods, 2, 153-157.

https://doi.org/10.1016/j.jff.2010.02.002

34. Savić, A., Jarić, S., Dajić-Stevanović, Z., Duletić-Laušević, S. (2019). Ethnobotanical study and traditional use of autochthonous pear varieties (Pyrus communis L.) in southwest Serbia (Polimlje). Genetic Resources and Crop Evolution, 66, 589-609.

https://doi.org/10.1007/s10722-018-00734-w
35. Sharma, K., Pasricha, V., Satpathy, G., Gupta, R.K. (2015). Evaluation of phytochemical activity of raw Pyrus communis L, an underexploited fruit. Journal of Pharmacognosy and Phytochemistry, 3, 46-50.

36. Singleton, V.L., Rossi, J.A. (1965). Colometric of total phenolics with phosphomolybdic-phosphotungstic acid reagents. American Journal of Enology and Viticulture, 16, 144-158.

37. Szwajgier, D., Borowiec, K. (2012). Screening for cholinesterase inhibitors in selected fruits and vegetables. Electronic Journal of Polish Agricultural Universities, 15, art. no. 6.

38. Šavikin, K., Živković, J., Zdunjić, G., Dojčinović, B., Menković, N. (2014). Phenolic and mineral profiles of four Balkan indigenous apple cultivars monitored at two different maturity stages. Journal of Food Composition and Analysis, 35, 101-111. https://doi.org/10.1016/j.jfca.2014.05.004

39. Šavikin, K., Živković J., Alimpić, A., Zdunjić, G., Janković T., Duletić-Laušević, S., Menković, N. (2018). Activity guided fractionation of pomegranate extract and its antioxidant, antidiabetic and antineurodegenerative properties. Industrial Crops \& Products, 113, 142-149.

https://doi.org/10.1016/j.indcrop.2018.01.031

40. Taylor, R. (1990). Interpretation of the correlation coefficient: a basic review. Journal of Diagnostic Medical Sonography, 6(1), $35-39$.

https://doi.org/10.1177/875647939000600106

41. Wilson, D.W., Nash, P., Buttar, H.S., Griffiths, K., Singh, R., De Meester, F., Takahashi, T. (2017). The role of food antioxidants, benefits of functional foods, and influence of feeding habits on the health of the older person: an overview. Antioxidants, 6(4), art. no. 81 .

https://doi.org/10.3390/antiox6040081 